\title{
Design and construction of Zambezi River Bridge, Mozambique
}

1 António J. Reis PhD

Technical Director, GRID Consulting Engineers, Lisbon, Portugal

2 José J. Oliveira Pedro PhD

Civil Engineer, GRID Consulting Engineers, Lisbon, Portugal
3 Behnam Dalili CEng

Civil Engineer, WSP International, Stockholm, Sweden
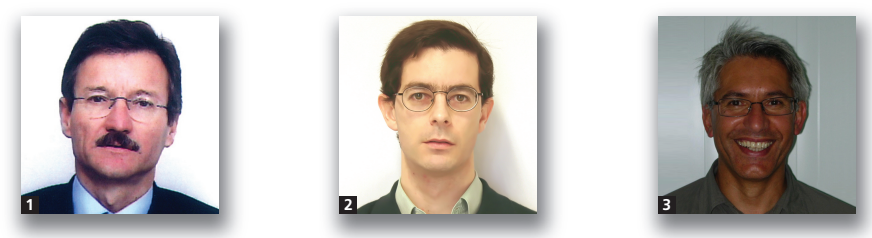

The Zambezi River Bridge between Caia and Chimuara is one of the longest and most important bridges built in Africa in recent years. The $2376 \mathrm{~m}$ long bridge provides a vital connection between the south and north of Mozambique, substituting the ferry connection to the national road 1 that has existed for almost 50 years. The topography of the site, the deep foundations, the size and significance of the river channel and the environmental sensitivities shaped almost every aspect of the bridge design and construction presented here, including the route selection, the structural forms and the construction methods.

\section{Introduction}

The new Zambezi River Bridge is one of the longest in Africa and forms an important link in the motorway network of South African Development Community member countries, functioning as a part of the coastal road extending from Kenya, through Tanzania and Mozambique, to South Africa (Figure 1).

This new crossing carries a two-lane carriageway for the national road 1 on a $2376 \mathrm{~m}$ long bridge and $2 \cdot 1 \mathrm{~km}$ long new road, all as part of a $€ 66$ million (excluding taxes) design and construct project that was built on behalf of the National Road Administration of Mozambique (ANE), and co-financed by the European Commission and the Governments of Italy and Sweden.

WSP International Sweden/Louis Berger Group (LBG)/GRID Consulting Engineers were appointed as the engineer for this project, carrying out during the period of 2003-2005:

the collection and study of existing data and the review of previous designs and proposals

the selection of preliminary design alternatives and preparation of preliminary cost estimates

the performance of pre-design studies and investigations

the performance of an environmental impact assessment study, economic impact studies and cost-benefit and risk analyses

the execution of a base case design for the bridge and road to be followed by the contractor

the preparation of documentation for the 'detailed designbuild' tender call.

Four proposals were received during the 2-month tender period, beginning in September 2005. In February 2006 MotaEngil/Soares da Costa JV was awarded the lump sum contract for the works, with a start date of March 2006 and a designconstruction period of 36 months. The contractor appointed consultant Betar as the detailed designer. WSP/LBG/GRID was retained by ANE as their technical consultants, evaluating tenders, supervising the detail design and acting as the engineer during construction. The bridge was opened to traffic in August 2009

\section{Review of previous studies}

The first design study for the Zambezi Bridge was presented by Edgar Cardoso in 1971 (Cardoso, 1971). A multiple span prestressed concrete box-girder deck was proposed, with a total length of $2340 \mathrm{~m}$, subdivided into 32 intermediate spans of $70 \mathrm{~m}$ and two end spans of $50 \mathrm{~m}$. The deck was a continuous structure along four typical $70 \mathrm{~m}$ spans. A horizontal straight alignment was defined. The $9 \cdot 2 \mathrm{~m}$ wide deck was designed to 


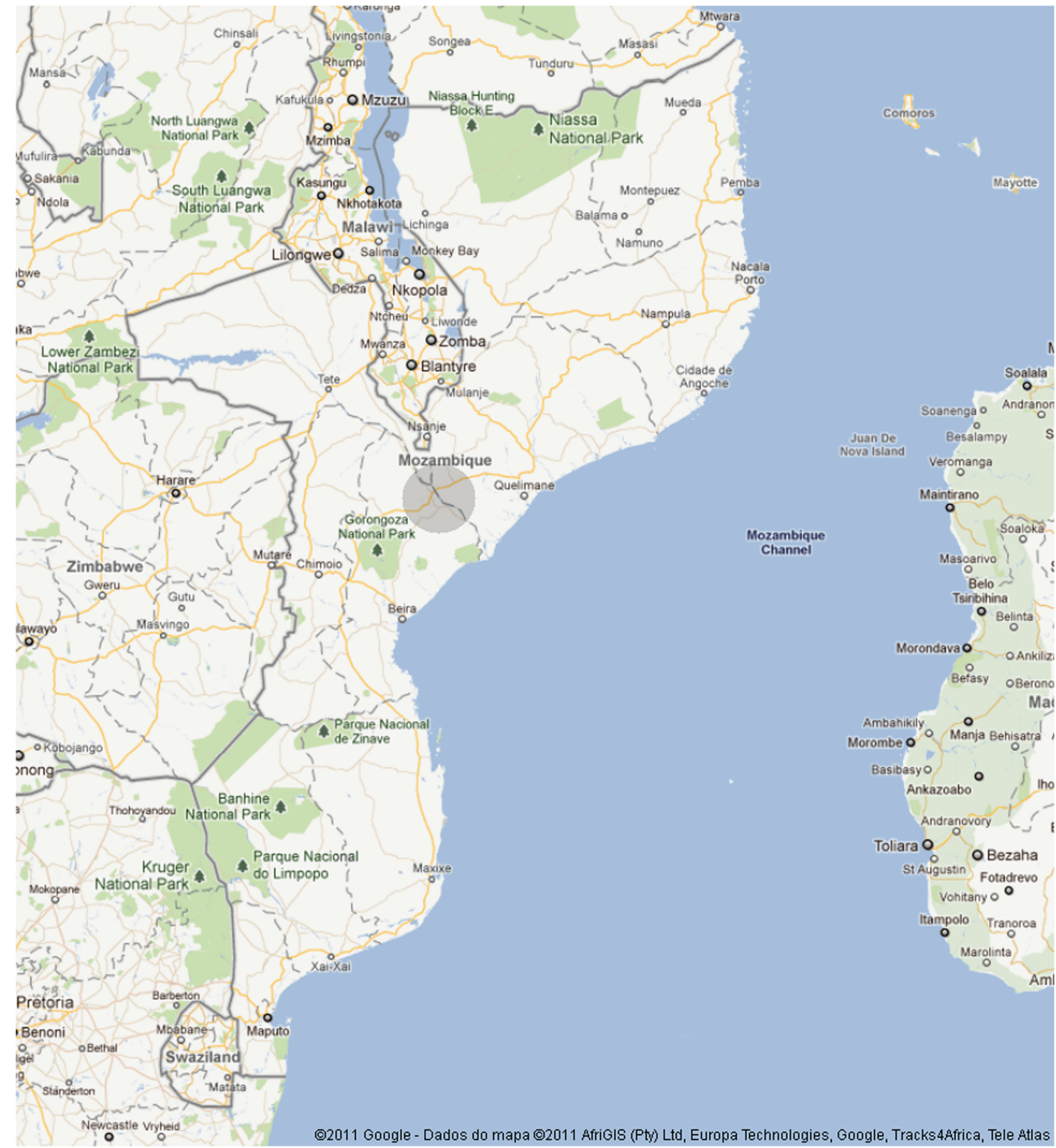

(a)

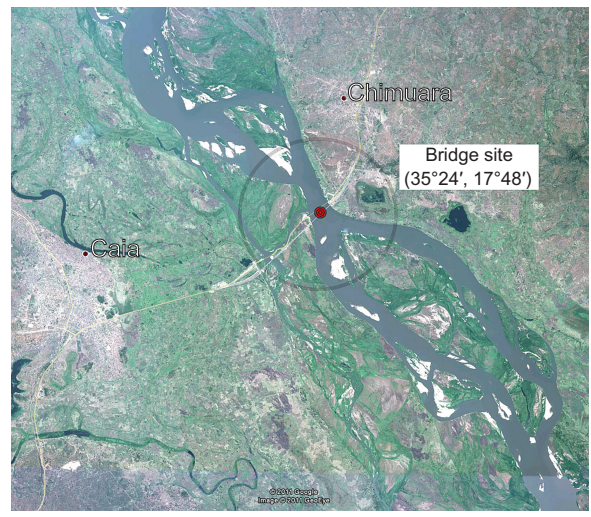

(b)

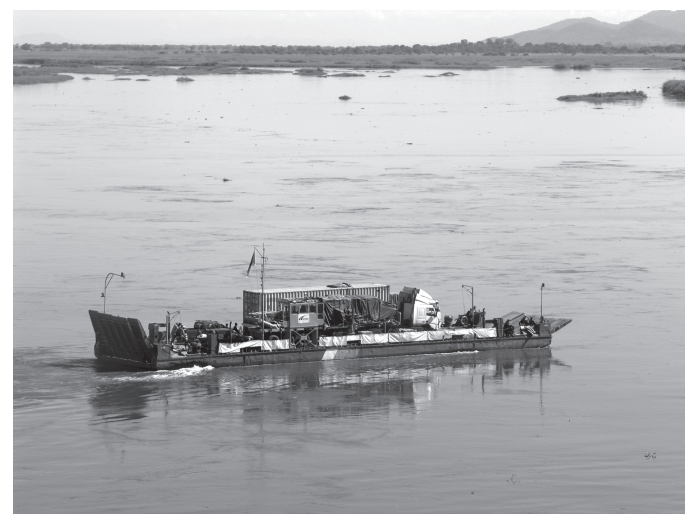

(c)

Figure 1. Mozambique map, Caia/Chimuara mapping area and ferry used to connect to the national road 1 
Design and construction of

Zambezi River Bridge,

Mozambique

Reis, Oliveira Pedro and Dalili accommodate two $3.6 \mathrm{~m}$ traffic lanes and two walkways; $1.0 \mathrm{~m}$ wide each (Reis, 2006).

From a historical point of view, it is interesting to note the bridge was designed with external prestressing, which is certainly one of the earliest experiences of such a design after its first use in the Aue Bridge, Germany, completed in 1937 (Menn, 1991), and the more recent return to external prestressing with Jean Müller in the 1980s. Very slender webs with $0 \cdot 16 \mathrm{~m}$ thickness were adopted by Cardoso in the variable depth box girder $-3 \cdot 1 \mathrm{~m}$ deep at mid-span and $4 \cdot 2 \mathrm{~m}$ deep at pier sections. The box-girder deck was designed to be cast in place, span by span, with a moving scaffolding. The piers were made of two circular pier shafts interconnected by a slender $0.20 \mathrm{~m}$ thick concrete wall, supported by a pile cap and six bored piles of $1.0 \mathrm{~m}$ diameter.

Construction based on the original design started 1976/1977. After completion of the two abutments and the first two piers on the south abutment side, the construction stopped. The exact reason for this decision was never made clear, but unexpected difficulties in providing access for materials to the deck and scaffolding support problems were reported. In 1978, a variant construction method was commissioned by the contractor, employing a precast segmental balanced cantilever scheme. The first two piers already built were demolished, as the design dead loads were then higher than those predicted in the original design by Cardoso. However, the new piers were never built, because the contractor had to abandon the site in $1981 / 1982$ due to the outbreak of civil war. In 1982, the contractor presented a new design-build proposal, with a $32 \times$ 70 plus $2 \times 44=2328 \mathrm{~m}$ total bridge length, but construction remained stopped during the civil war period (CETA and Construções Técnicas, 1982; Construções Técnicas, 1982).

In 1997 and 2001, Mott MacDonald and Brokonsult presented new studies returning to the bridge design (Brokonsult, 2001; Mott MacDonald, 1997). The second study proposed a bridge river crossing at the position of the existing abutments, with a similar scheme as per the 1971 Portuguese design. However, Brokonsult (2001) proposed two differences from the original design, namely a constant depth for the box girder and two launched steel truss girders on provisional supports on both sides of the column tops for deck construction purposes. However, to keep the vertical deformability at reasonable levels during concrete pouring, the $70 \mathrm{~m}$ long spans required scaffolding that was ultimately deemed too expensive and too heavy.

Another disadvantage of the early designs refers to the number of expansion joints adopted for the deck. The deck was divided into $210 \mathrm{~m}$ or $280 \mathrm{~m}$ segments, separated by hinges and expansion joints, respectively, in the Brokonsult and Cardoso designs. Although this was at the time a typical solution, continuous decks of $500-600 \mathrm{~m}$ could be adopted with the benefit of eliminating maintenance problems in hinges and expansion joints.

Finally, the Brokonsult proposal and the original design shared the main disadvantage of keeping the same span lengths along the whole length of the bridge. Clearly, the conditions for the execution of pile foundations along the $650 \mathrm{~m}$ of the Zambezi channel were totally different from those in the remaining bridge length. In fact, during most of the year, pile foundations could be executed from dry land along at least $1650 \mathrm{~m}$. In the remaining $650 \mathrm{~m}$ this work had to be done within a permanent water table of $4-8 \mathrm{~m}$ depth. Furthermore, ferry services were expected to continue during construction only along this $650 \mathrm{~m}$ section of the crossing. Consequently, longer spans in this zone were the more logical solution, as an addendum to the Brokonsult report named 'Additional bridge study' concluded.

In 2003, a report presented by Vägverket Konsult (Karlsson, 2003) also proposed a main bridge over the Zambezi channel, with a main span of $160 \mathrm{~m}$ executed by the balanced cantilever scheme. However, five pier foundations had to be executed in the water, which only a multiple long-span deck could avoid.

Finally, in 2003 the WSP/LBG/GRID group was selected on an international design tender to develop a new engineering design for the project, supervise detailed design and construction works.

\section{Preliminary design studies}

\subsection{Road design}

At the request of the client, the horizontal alignment of the proposed bridge was to stay with the original design in order to make use of the existing abutments. With respect to the vertical bridge alignment, the terms of reference (TOR) for the detailed engineering studies required that the design of the bridge should meet with the following requirements for the bridge (WSP/LBG/GRID, 2004, 2005):

- It must safely pass a 100-year flood with a minimum freeboard of $13 \mathrm{~m}$ over three spans to allow for safe ship passage under the bridge (level $27.9 \mathrm{~m}$ ).

- It should be capable of safely passing road traffic during or immediately after a 1000-year flood event (level $29 \mathrm{~m}$ ).

- The longitudinal alignment design was to have an aesthetically pleasing profile of the bridge and match the requirements of the TOR. To achieve these goals the following concepts were implemented:

- An arched alignment over the Zambezi channel to provide the $13 \mathrm{~m}$ minimum clearance under the main bridge, with 
the highest point on the arch at the middle of the river, which is always the most aesthetically pleasing solution; the $13 \mathrm{~m}$ minimum clearance was fixed for the expected navigable condition requirements in the Zambezi River.

A gradient of $0.5 \%$ over the approach viaduct, with a low point approximately halfway in the viaduct, in order to provide for ease of drainage.

The road cross-section consisted of $11 \mathrm{~m}$ surfaced roadway (two $3.5 \mathrm{~m}$ lanes plus two $2.0 \mathrm{~m}$ surfaced shoulders). The above road cross-section ties on to the proposed bridge crosssection of two $3.6 \mathrm{~m}$ lanes plus two $2.5 \mathrm{~m}$ surfaced shoulders, with a transition over a distance of $30 \mathrm{~m}$ at each end (on the approach road side) of the bridge.

\subsection{Hydrology and hydraulic studies}

The Zambezi River at Caia is a typical braided river, with one large sand island and two channels. The channels are called the Zambezi channel near the left bank and the Sena channel near the right bank. The Zambezi River is the fourth largest river in Africa and the largest that flows into the Indian Ocean. It is $2700 \mathrm{~km}$ long and it has a total catchment area of approximately $1250000 \mathrm{~km}^{2}$. The river crosses eight countries before discharging into the Indian Ocean. Its source is in the northwestern corner of Zambia close to the junction of the borders of Angola, Zambia and the Democratic Republic of Congo. The altitude of the source is approximately $1600 \mathrm{~m}$. Upstream of Victoria Falls the river flows mainly through flat areas, including the large Barotse Plains. The river course between Victoria Falls and downstream of Tete was originally characterised by many rapids and pen plains. However, the huge Kariba and Cabora Bassa Reservoirs, with a combined storage volume of almost $250 \times 10^{9} \mathrm{~m}^{3}$ and longer than $500 \mathrm{~km}$ of total water surface length, have significantly modified the character of the river flow.
Between Cabora Bassa and Lupata $(70 \mathrm{~km}$ downstream of Tete) the river flows in an $800-1000 \mathrm{~m}$ wide stable channel. Downstream of Lupata the Zambezi enters its wide floodplain. The river has a braided channel pattern with a total width of $3-5 \mathrm{~km}$. The braided pattern is unstable and is prone to great changes after larger floods. The banks are undefined and during floods the floodplain storage is very important. An additional circumstance is the escape of floodwaters along certain reaches of the right bank towards the interlinked Pungue catchment south of the Zambezi. The Caia bridge site is approximately $280 \mathrm{~km}$ downstream of Tete and $150 \mathrm{~km}$ upstream of the Zambezi mouth.

The climate is generally tropical continental with dry winters and wet summers, and tropical maritime with no true dry season. The mean annual rainfall varies between 500 and $1500 \mathrm{~mm}$. At Caia the mean annual rainfall of the catchment is close to $1000 \mathrm{~mm}$. The mean annual flow at Kariba Dam is $1450 \mathrm{~m}^{3} / \mathrm{s}$, at Cabora Bassa Dam $2400 \mathrm{~m}^{3} / \mathrm{s}$ and at Tete $2450 \mathrm{~m}^{3} / \mathrm{s}$. The mean annual flow at Caia is unknown but is estimated to be slightly greater than the flow at Tete due to the contribution from tributaries and groundwater, assuming the river flow is restricted to the channel(s). The proposed flood peak frequencies at Caia were essentially based on the analysis of the annual maximum daily discharges at Tete carried out by Mott MacDonald in 1997.

The recommended Brokonsult 10-100-year flood peaks are also presented in Table 1 . The same table reflects the Brokonsult calculated 10-100-year outflow peaks from Cabora Bassa. The reason for adopting the Tete flood peak frequencies for Caia was twofold. First, and most importantly, Tete was the only reliable flow gauging station downstream of Cabora Bassa with a long and continuous record (from 1945). Second, it was not possible to estimate between the two sites

\begin{tabular}{lrrrrrrrr}
\hline $\begin{array}{l}\text { Return } \\
\text { period (years) }\end{array}$ & \multicolumn{1}{c}{ Source } & 10 & 20 & 50 & 100 & 200 & 500 & 1000 \\
\hline $\begin{array}{l}\text { Flood peak } \\
\text { at Tete }\left(\mathrm{m}^{3} / \mathrm{s}\right)\end{array}$ & $\begin{array}{l}\text { Mott MacDonald } \\
\text { report }\end{array}$ & 12400 & 14000 & 16300 & 18000 & - & - & - \\
$\begin{array}{l}\text { Cabora Bassa } \\
\text { outflow }\left(\mathrm{m}^{3} / \mathrm{s}\right)\end{array}$ & Brokonsult report & 11090 & 13080 & 15640 & 17550 & - & - & - \\
$\begin{array}{l}\text { Peak discharge } \\
\left(\mathrm{m}^{3} / \mathrm{s}\right)\end{array}$ & 12400 & 14000 & 16000 & 18000 & 20000 & 23000 & 25000 \\
$\begin{array}{l}\text { Estimated peak } \\
\text { discharge }\left(\mathrm{m}^{3} / \mathrm{s}\right)\end{array}$ & WSP/LBG/GRID & 11600 & 14000 & 18000 & 21000 & 23000 & 26000 & 29000 \\
Water level at & 14 & $25 \cdot 77$ & $26 \cdot 18$ & $26 \cdot 77$ & $27 \cdot 10$ & $27 \cdot 41$ & $27 \cdot 76$ & 28.09
\end{tabular}


Design and construction of

Zambezi River Bridge,

Mozambique

Reis, Oliveira Pedro and Dalili the balance of flood inflow (tributaries) and flood flow losses (storage in the floodplains and escaping flow volumes along the right bank). Therefore, the only reasonable solution had been to assume zero balance. On the other hand, the TOR also stated that the hydraulic analyses should be based on the following peak flow values as determined by Brokonsult (2001).

As the bridge and approach road levels ultimately depend on the estimated design flood peaks, a critical examination of the above values was called for in the frame of the bridge design. The methodology applied by Brokonsult to arrive at the above recommended values at Caia (i.e. either a combination of Cabora Bassa outflow or a reduced sum of downstream tributary peaks or accepting the Tete results as representative) was adopted. Two independent statistical models were used to perform a case sensitive analysis, which provided flood peak frequencies for the bridge site of Table 1 . The 100 and 1000year floods were then evaluated to obtain the stage discharge curve at the bridge site. In order to model the flow accurately in the river the roughness parameters along each cross-section had to be defined. The river was divided into three sections that is, the left bank, main channel and right bank. The roughness values used for each of the three sections were $\mathrm{n}=$ 0.075 for the left and right banks and $n=0.033$ for the main channel.

The estimated $12500 \mathrm{~m}^{3} / \mathrm{s}$ peak flow of the 1997 flood was used to verify the model parameters. It was noticed that the road embankment contributed significantly to the increased water levels. Apparently the embankment created a backwater effect to compensate for the additional head loss in the Zambezi channel due to the increased flow velocity (WSP/LBG/GRID, $2004,2005)$. From the flood marks it was determined that the maximum water level was at approximately $27.5 \mathrm{~m}$ above datum. It was further indicated that if the embankment was not in place the maximum water level would have been approximately $1.3 \mathrm{~m}$ less. Consequently, it was decided this road embankment should be removed after the bridge construction and the Sena channel opened. This state was also analysed and a level of $25.92 \mathrm{~m}$ was obtained in the hydraulic model, with an estimated slope of $0.02 \%$ for the river downstream cross-section. The same analysis was then performed considering the bridge piers. The water levels obtained at the bridge structure were $27 \cdot 16 \mathrm{~m}$ and $28.09 \mathrm{~m}$ for the 100 and 1000 -year flood peaks, respectively. Furthermore, it was concluded that the bridge piers did not have a significant effect on the upstream water level. The water level was still controlled by the water levels downstream of the bridge.

A sensitivity analyses was finally performed, increasing the roughness parameters in the river increased to $0 \cdot 040$ and 0.080 for the main channel and floodplains, respectively, and reducing slope to $0.015 \%$ for the river downstream crosssection. For this most severe scenario, the water levels at the bridge site could be as high as $27.90 \mathrm{~m}$ for the 100 -year flood and $28.98 \mathrm{~m}$ for the 1000 -year flood.

\subsection{Geological and geotechnical studies}

In the Caia area, the southern bank of the Zambezi River was underlain by soft rock, corresponding to very friable conglomeratic sandstone of the Inhaminga formation, of Cenozoic age, overlain by alluvial quaternary sediments, with thicknesses of approximately $65 \mathrm{~m}$ below the ground surface. In contrast, the northern bank of the river was underlain by a mantle of transported and residual soils overlying the gneiss and granolithic basement of the Metola group. These rocks were frequently cut by dikes and sheets of Jurassic age gabbros. The gneiss bedrock was quite shallow on the northern bank, in the range of $1-3 \mathrm{~m}$. The interpretation of the 10 boreholes performed during 2004 and results from previous surveys supported the geological section of the crossing (Figure 2), composed by WSP/LBG/GRID, 2005:

C1 Alluvial deposits with interbedded layers of sandy and clayey soils up to $56 \mathrm{~m}$

C2 Coarser sediments (gravely sands, sandy gravels and gravels, with cobbles and boulders) in the basis of the alluvial deposits of the paleo channel; up to $11 \mathrm{~m}$ deep

C3 Conglomeratic sandstone composed of very soft rocks and friable sandstones, decomposed at the top in clayey, sandy and gravely soils

C4 Gneiss basement outcrops forming the bedrock of the actual channel of the Zambezi River and the northern bank, decomposed at the top up to $5 \mathrm{~m}$ deep.

It should be noted that, in spite of all previous geological investigation results, at the time the bridge design was developed by WSP/LB/GRID the level of the bedrock was unknown because none of the previous boreholes had reached the bedrock level. This was the main reason for undertaking 10 new boreholes for the new design.

The water level reported in the boreholes was always near the surface, in direct correspondence with the water level in the river. Taking into account these conditions, namely the presence of a thick layer of alluvial deposit, the foundations of the structure had to be made by piles. Even in the zone of the northern bank, where the presence of a gneiss basement was detected, the rock was decomposed to a depth that did not allow shallow foundations. 


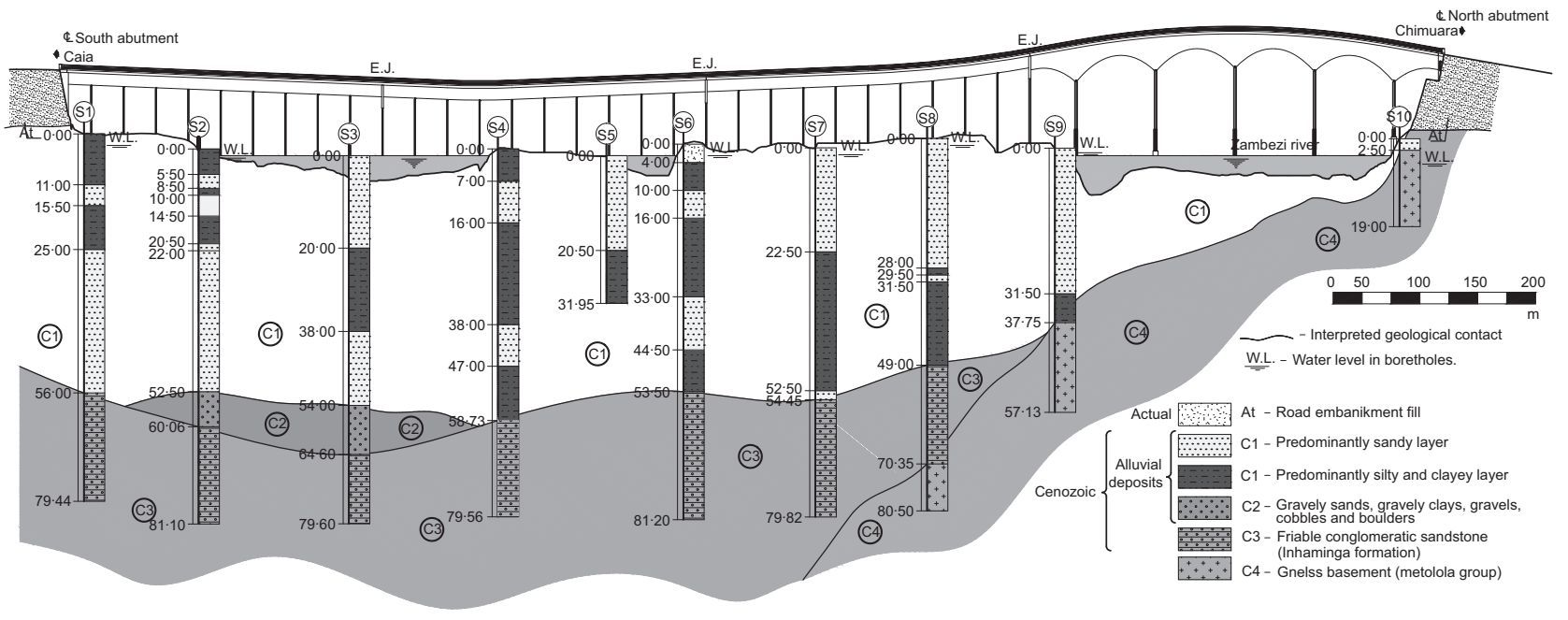

Figure 2. Geological section of the bridge crossing (elevations in $\mathrm{m}$ )

The piles were designed to carry the vertical load by a socket action within the rock, with part of the load carried by skin friction and part by end bearing. Settlements were also considered by an assessment of the deformation of the rock mass. The design parameters were determined from available data, mainly standard penetration test results from 1965, 1982 and 2004 surveys.

Pile testing was planned to be executed ahead of pile construction to confirm design assumptions. The contractor presented an alternative solution for these tests using the Osterberg cell (known as the O-cell) procedure, avoiding the installation of a reaction beam and anchor piles (LOADTEST, 2007). A $540 \mathrm{~mm}$ O-cell was located $5 \cdot 2 \mathrm{~m}$ above the tip of the $1.5 \mathrm{~m}$ dia. pile to mobilise an equal resistance above and below the O-cell, maximising the applied load. The O-cell was attached to the reinforcing steel cage of the pile (Figure 3). The pile was concreted with the $\mathrm{O}$-cell in place and penetrated $5 \mathrm{~m}$ into the conglomeratic sandstone complex.

The test consisted of separating the pile in two portions above and below the $\mathrm{O}$-cell - inducing hydraulic pressure in the cell. The upper pile movement was conditioned only by the side shear strength mobilised along the upper part of the pile, while the lower pile movement was controlled by the side shear strength of the lower part of the pile plus the base resistance. The test proceeded until full mobilisation of the side shear strength on the upper part of the pile. To perform the test, the pile was instrumented with strain gauges embedded in the pile in order to measure deformations in the pile at different levels. Two linear vibrating wire displacement transducers were positioned between the lower and upper plates of the O-cell assembly to measure its expansion. The load test was performed using 13 loading increments. The pressure applied in the O-cell reached a bidirectional O-cell load of $10 \cdot 89 \mathrm{MN}$. Each load increment was kept constant for a minimum of $30 \mathrm{~min}$ to a maximum of $180 \mathrm{~min}$ by manually adjusting the $\mathrm{O}$ cell pressure until a maximum creep criterion of $0.05 \mathrm{~mm} /$ 10 min was met.

For the alluvial deposits located above the O-cell, the differences between side shear strength in numerical model and test results were small (Figure 3) (Melo, 2007). The largest difference occurred due to the side shear strength that could be mobilised at the pile section below the O-cell - that is, in the friable conglomeratic sandstone. It must be pointed out that there were no experimental data for the geotechnical characterisation of this material, thus side shear strength was minimised in the numerical model. Load test results showed that both base and side shear strength were fully mobilised below the O-cell. An equivalent top load-load/settlement curve was also obtained using the upward top of the O-cell and downward base of the O-cell data and adjusting it for the additional elastic compression of the pile that would occur in a top load test (Figure 3). A good agreement between the test results and the numerical results for a simulated load test was obtained.

The predicted performance of the piles was very close to that observed, which, on the one hand, allowed validation of the methodology used to calibrate the soil models for the numerical analyses and, on the other hand, allowed emphasis of the adequacy of the O-cell procedure for pile load tests. Test results enhanced the influence of the piles penetrating at least $5 \mathrm{~m}$ on the conglomeratic sandstone, because a significant part of the mobilised lateral friction occurred in these materials. For 


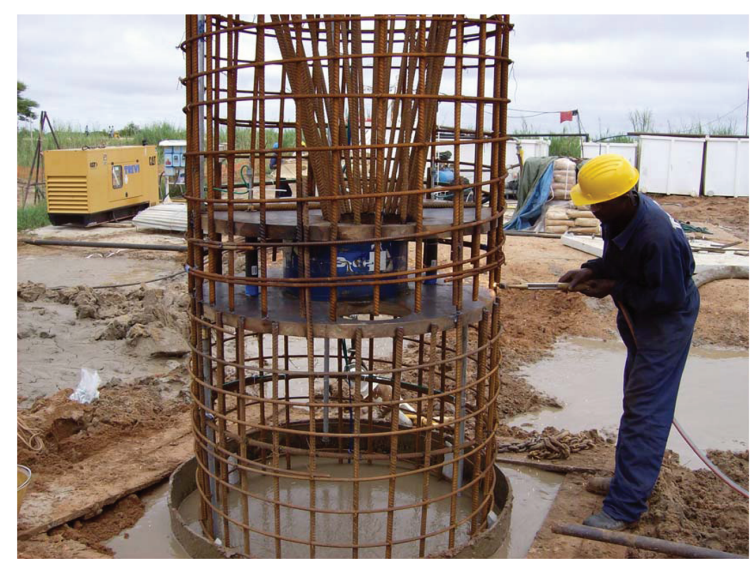

(a)

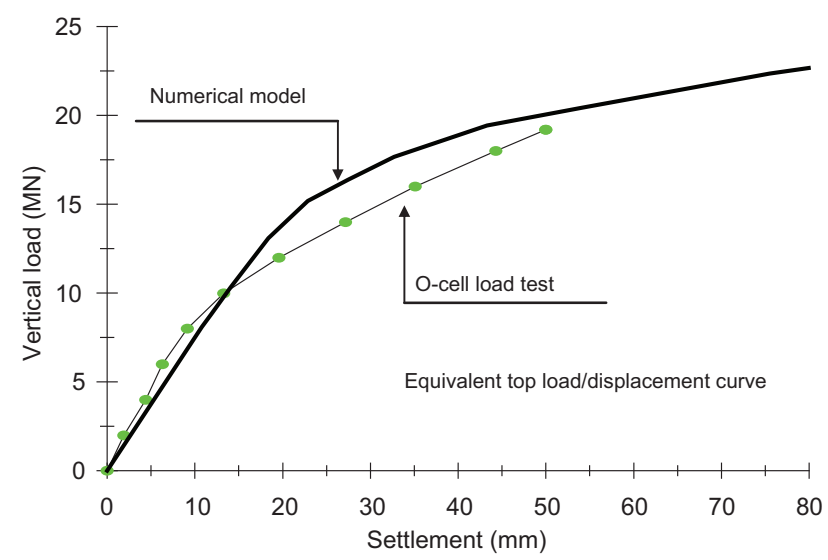

(c)

Figure 3. O-cell load test of a pile $1.5 \mathrm{~m}$ in diameter (Melo, 2007)

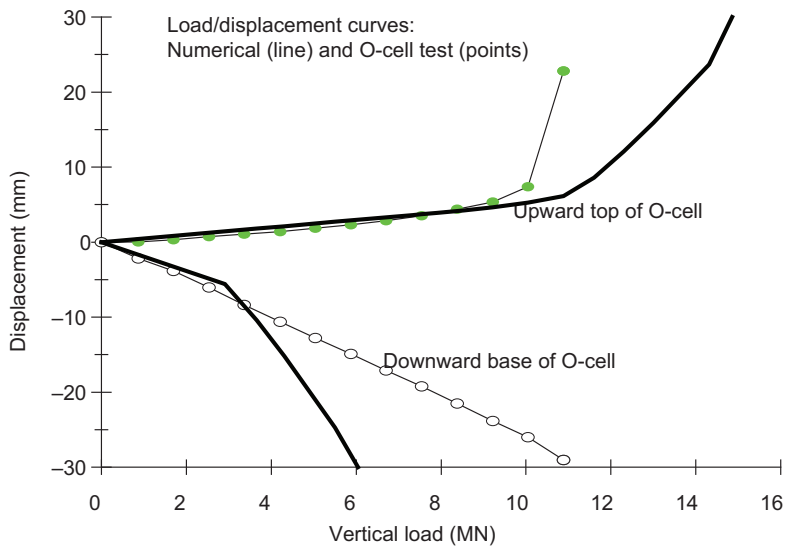

(b) a maximum working load of $8.4 \mathrm{MN}$, corresponding to a pile stress of $5 \mathrm{MPa}$, the tested pile experienced a $1 \cdot 1 \mathrm{~cm}$ settlement, accepted as allowable differential pier settlement for the deck structure (Melo, 2007).

Finally, according to the numeric models the $2 \cdot 0 \mathrm{~m}$ dia. piles on the Zambezi channel needed to penetrate $5 \mathrm{~m}$ into the gneiss massif, under a level at which the uniaxial compressive strength was at least $10 \mathrm{MPa}$. This requirement ensured the required bearing capacity, correspondent to a maximum of $5.5 \mathrm{MPa}$ in-service pile stress and $2 \mathrm{~cm}$ maximum settlement (WSP/LBG/GRID, 2005).

\subsection{Bridge conceptual design}

To meet the client's requirements, preliminary studies were undertaken to determine the deck width (between 12 and $16 \mathrm{~m}$ ), in consideration of forecast traffic demands. Finally, a deck cross-section $16 \mathrm{~m}$ wide was retained. At the Zambezi channel, a $137 \cdot 5 \mathrm{~m}$ long typical span was defined to ensure the required vertical clearance on the channel and reduce the risk of ship collision (WSP/LBG/GRID, 2004). The horizontal road alignment of the original design was kept, as imposed by the TOR documents.

Under 'normal' flow conditions, the river cross-section could be split into three different parts: the Sena channel in the south and the Zambezi channel in the north separated by an alluvial island in the middle. The Zambezi channel was approximately $600 \mathrm{~m}$ wide in normal flow conditions. Therefore, the following structures were proposed: an 'approach bridge' 1600-1700 m long and a 'main bridge' of $600-700 \mathrm{~m}$ total length. The foundation for the two structures differed considerably. The former could be executed on dry land for most of the year, the last needed to be executed in the water.

For the main bridge, the main considerations were: the number of pier foundations in the water; the need to keep the minimum spans to $137.5 \mathrm{~m}$; and the design of a structural solution with 
an execution method as simple as possible in order to maximise the use of local labour. The preference for prestressed concrete bridges was expressed by ANE, excluding composite boxgirder options. Two continuous decks were studied at the preliminary design stage: an $80+4 \times 137 \cdot 5+80=710 \mathrm{~m}$ deck, to fulfil the navigation requirements and a $105+3 \times 167$ $+105=711 \mathrm{~m}$ deck, reducing from five to four the number of piers in the water.

Increasing the span above $170 \mathrm{~m}$ would result in a very deep box girder at the support sections, which is not compatible with the required vertical clearance. Moreover, box girders built by the cantilever method with spans above 150-180 m are likely to be less economically advantageous compared with cable-stayed or extradorsal prestressed options. The most economic solution for the approach bridge spans $(45-50 \mathrm{~m})$ was to cast in-situ decks, executed with a formwork launching girder or by incremental launching. Precast girders placed using a launching girder, with smaller spans $(35-45 \mathrm{~m})$ were also envisaged. The limits for economic feasibility for cast in place box-girder decks executed with a formwork-launching girder raise from 50 to $60 \mathrm{~m}$. Therefore, three options were proposed for the approach bridge (Figure 4):

(a) a box-girder deck, longitudinally and transversally prestressed for typical spans of $56 \mathrm{~m}$

(b) a girder deck with longitudinal and transverse prestressing, for typical spans of $45 \cdot 30 \mathrm{~m}$

(c) a deck with prestressed precast girders and a cast in-situ reinforced concrete slab, for the same $45 \cdot 30 \mathrm{~m}$ typical spans.

An evaluation of the main structural materials for all options is presented in Table 2, divided into materials for the deck, piers and foundations. All quantities are per longitudinal metre of the bridge. A preliminary cost estimate was presented, showing the advantages of adopting longer spans for the approach bridge, but not for the main bridge. Based on these results, ANE selected alternative $(a)$ for the base case design of both bridges.

\section{Base case design}

\subsection{General bridge layout}

The base case design (WSP/LBG/GRID, 2005) fixed a $2376 \mathrm{~m}$ long bridge, divided into a $710 \mathrm{~m}$ long main bridge and three approach bridge sections of $546 \mathrm{~m}+2 \times 560 \mathrm{~m}=1666 \mathrm{~m}$ (Figure 5). Therefore, three internal and two end expansion joints were required; the former located at the transition piers and the latter at the abutments.

Prestressed concrete box girders were adopted on both the approach and main bridge decks, supported by a set of neoprene teflon pot bearings transferring the loads to the reinforced concrete piers. Each pier shaft transfers the loads to the piles using pile caps. The reinforced concrete abutments also have pile foundations of $1.2 \mathrm{~m}$ diameter.

\subsection{Main bridge}

The $710 \mathrm{~m}$ long main bridge includes four inner spans of $137.5 \mathrm{~m}$ and two end spans of $80 \mathrm{~m}$ (Figure 6). The box-girder deck has a parabolic profile with a varying depth from $7.5 \mathrm{~m}$ over the central piers to $3.5 \mathrm{~m}$ at mid-span and at the edges of the end spans. The $16 \mathrm{~m}$ wide top slab includes a $12.2 \mathrm{~m}$ wide road platform and a $1.90 \mathrm{~m}$ wide walkway on each side. The $3.75 \mathrm{~m}$ deck overhangs have a variable thickness from $0.22 \mathrm{~m}$ at the edge to $0.50 \mathrm{~m}$ at the web link. The slab between webs is $8.5 \mathrm{~m}$ long and $0.30 \mathrm{~m}$ deep at mid-span section (Figure 7).

A web constant thickness of $0.70 \mathrm{~m}$ was adopted up to the third segment. Then up to the 13th segment web thickness varies from $0.70 \mathrm{~m}$ to $0.45 \mathrm{~m}$, being constant in the remaining deck length. In order to control the compression induced by the hogging bending moment over the piers, the bottom flange has a maximum thickness of $1 \cdot 10 \mathrm{~m}$, and varies smoothly down to $0.22 \mathrm{~m}$ at the 10 th segment, being constant thereafter. Anchorage blocks are located at the top of the bottom flange close to the webs for anchoring internal continuity tendons. Deviation saddles, for external prestressing cables are inserted in ribs with $1.0 \mathrm{~m}$ thickness adjacent to the webs as well as at the diaphragm at support sections.

The pier diaphragms have several purposes - to resist shear and torsion, to transfer bearing reactions and to anchor all the external prestressing cables. The diaphragms typically $0.7 \mathrm{~m}$ thick, are enlarged to $1.5 \mathrm{~m}$ at the top and bottom areas, to insert the anchorage of the external cables and the bearing reactions, respectively.

The tubular shafts of the piers with heights from $7 \cdot 5$ to $11 \cdot 7 \mathrm{~m}$ have a hexagonal shape cross-section of $7 \mathrm{~m}$ by $4.7 \mathrm{~m}$ and $0.7 \mathrm{~m}$ thick walls (Figure 8). At the bottom of the piers level, an elliptical solid cross-section of $8.8 \mathrm{~m}$ by $5.4 \mathrm{~m}, 6.35 \mathrm{~m}$ height was adopted up to the level associated with the 100year flood return period. All piers, apart from pier 4, adopted foundations with six piles of $2 \mathrm{~m}$ diameter spaced at $5.0 \mathrm{~m}$, and pile caps $4 \mathrm{~m}$ deep and in plan dimensions of $14 \mathrm{~m}$ by $9.5 \mathrm{~m}$. Pier PB4 required eight piles of the same diameter, with a pile cap $4.5 \mathrm{~m}$ deep and $14 \mathrm{~m}$ by $12.5 \mathrm{~m}$ in plan dimensions, due to horizontal longitudinal seismic forces transmitted by the deck.

The piles adopted a permanent steel casing $16 \mathrm{~mm}$ thick, with lengths from $16 \mathrm{~m}$ to $51 \mathrm{~m}$ and a minimum penetration length of $5 \mathrm{~m}$ into layer $\mathrm{C} 4$. Concrete grade C35/45 is adopted in the deck, while piers, piles and foundations were made with 

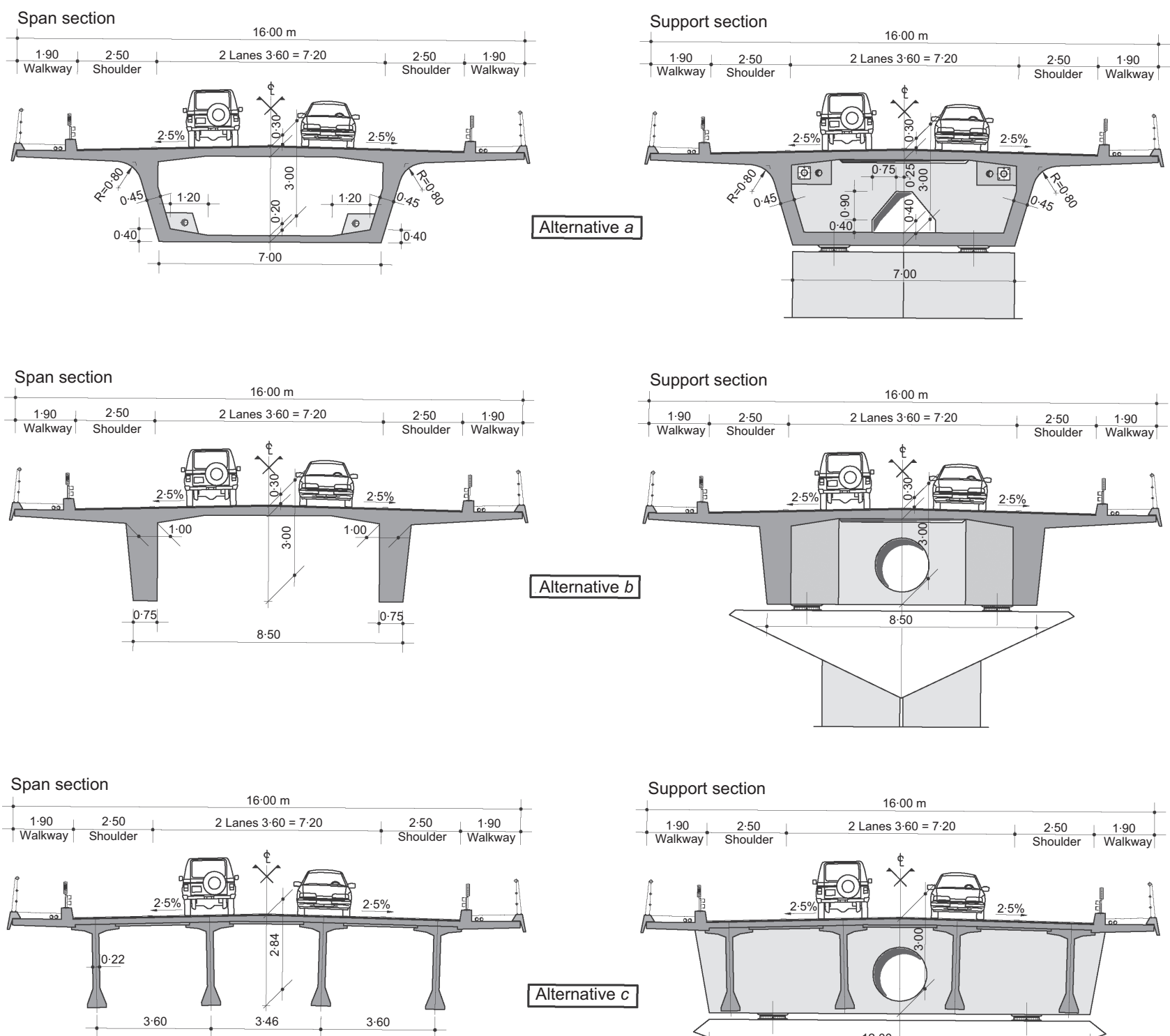

Alternative $c$

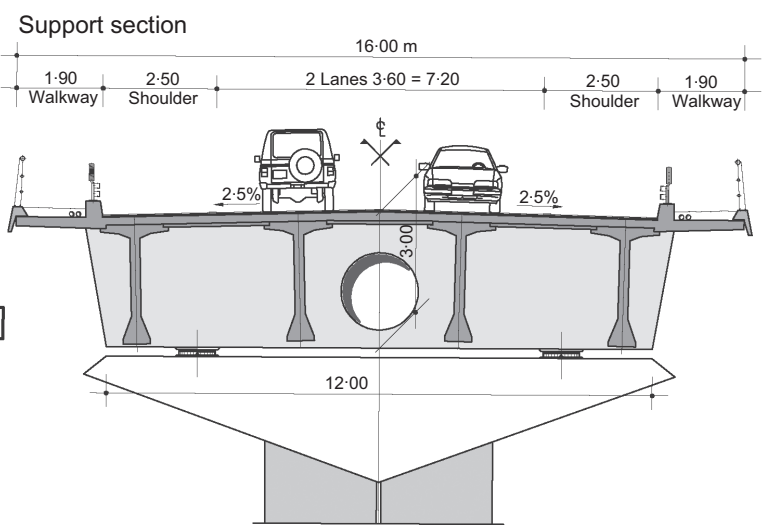

Figure 4. Alternative solutions for the approach bridge deck ((dimensions in $\mathrm{m}$ ) (WSP/LBG/GRID, 2004)

concrete grade $\mathrm{C} 30 / 37$. All piers and the north abutment are two sliding guided pot bearings resisting vertical and transverse loads but allowing longitudinal movements. Exception is made for pier PB4, which has two fixed pot bearings resisting vertical, longitudinal and transverse loads. Although the Zambezi region is not considered a high seismic area, seismic devices are adopted, providing the longitudinal link between the deck and the north abutment, in case of a seismic event. Two oleo-dynamic shock transmitters are adopted with a yielding force of $2500 \mathrm{kN}$ each and $500 \mathrm{~mm}$ displacement amplitude.

The cantilever prestressing cables are made of pairs of 19 or 12 strands (15 mm nominal diameter) in each segment web. For the typical $137 \mathrm{~m}$ spans, $1622 / 15 \mathrm{~mm}$ continuity cables run straight through the bottom flange in the vicinity of the webs, between anchor blocks. The $80 \mathrm{~m}$ end spans have eight 22/ $15 \mathrm{~mm}$ and four $12 / 15 \mathrm{~mm}$ continuity cables. Due to lack of 
Bridge Engineering

Volume 166 Issue BE2
Design and construction of

Zambezi River Bridge,

Mozambique

Reis, Oliveira Pedro and Dalili
Structural element

Deck

Concrete

Formwork

Mild reinforcement

Prestressing: longitudinal

Prestressing: transversal

Piers

Concrete

Formwork

Mild reinforcement

Foundation

Concrete

Formwork

Piles
Mild reinforcement

Alternative
$\left[\mathrm{m}^{3} / \mathrm{m}\right]$
$\left[\mathrm{m}^{2} / \mathrm{m}\right]$
$[\mathrm{kg} / \mathrm{m}]$
$[\mathrm{kg} / \mathrm{m}]$
$[\mathrm{kg} / \mathrm{m}]$
Alternative
$\left[\mathrm{m}^{3} / \mathrm{m}\right]$
$\left[\mathrm{m}^{2} / \mathrm{m}\right]$
$[\mathrm{kg} / \mathrm{m}]$
Alternative
$\left[\mathrm{m}^{3} / \mathrm{m}\right]$
$\left[\mathrm{m}^{2} / \mathrm{m}\right]$
$[\mathrm{kg} / \mathrm{m}]$
$[\mathrm{m} / \mathrm{m}]$

Approach bridge

Main bridge

Table 2. Main material quantities for preliminary design alternatives (WSP/LBG/GRID, 2004)

$(b)$
$9 \cdot 85$
$26 \cdot 69$
1083
314
116
$(b)$
$2 \cdot 96$
$4 \cdot 84$
400
$(b)$
$3 \cdot 70$
$1 \cdot 83$
$296 \cdot 3$
$5 \cdot 31$

(b)

$36 \cdot 75$

1394

360

116

(a)

$1 \cdot 81$

$7 \cdot 00$

272

(a)

$2 \cdot 99$

$1 \cdot 48$

$239 \cdot 5$

$4 \cdot 40$

$(c)$
$8 \cdot 63$
$41 \cdot 39$
1295
340
-
$(c)$
$2 \cdot 96$
$4 \cdot 84$
400

(c)

$3 \cdot 70$

$1 \cdot 83$

$296 \cdot 3$

$5 \cdot 31$

$\begin{array}{cc}(a) & (b) \\ 13 \cdot 41 & 14 \cdot 37 \\ 39 \cdot 66 & 42 \cdot 63 \\ 1865 & 2045 \\ 663 & 1400 \\ 106 & 106\end{array}$

(b)

$2 \cdot 87$

$3 \cdot 39$

264

(b)

$4 \cdot 54$

$1 \cdot 31$

$235 \cdot 9$

$0 \cdot 65$ space in the bottom flanges for continuity cables, external prestressing was adopted. Four external $27 / 15 \mathrm{~mm}$ cables are adopted at each span, running between diaphragms and passing by deviators at the third points in the span. Two additional external cables can be installed if needed. The slab prestressing is made of $4 / 15 \mathrm{~mm}$ tendons $1 \mathrm{~m}$ apart. At supports, and within $3 \mathrm{~m}$ vicinity, the tendon spacing is reduced to $0.7 \mathrm{~m}$. Four cables with 22 strands each are added to the pier diaphragms (Figure 9).

\subsection{Approach bridge}

The approach bridge is divided into three sections, one $546 \mathrm{~m}$ long and two $560 \mathrm{~m}$ long. Apart from the $42 \mathrm{~m}$ long span adjacent to the south abutment, all other spans are $56 \mathrm{~m}$ long.
The $3 \mathrm{~m}$ deep box-girder deck has the same top slab design as the main bridge. A constant thickness of $0.2 \mathrm{~m}$ is adopted for the bottom flange over $32 \mathrm{~m}$ and $0.4 \mathrm{~m}$ in a $20 \mathrm{~m}$ length centred with the piers' centre line (Figure 10). The inclined webs have a constant thickness of $0.4 \mathrm{~m}$ throughout $45.8 \mathrm{~m}$, increasing to $0.6 \mathrm{~m}$ at $3.1 \mathrm{~m}$ of the piers. Pier diaphragms $0.7 \mathrm{~m}$ thick transmit the loads to the pair of pot bearings underneath. Deviation saddles are adopted at supports and quarter-span deck sections, allowing additional external prestressing to be installed, if required.

The piers' height varies from $11 \cdot 1 \mathrm{~m}$ to $19 \cdot 5 \mathrm{~m}$ with a constant shaft tubular cross-section. The typical hexagonal shape crosssection, $7 \mathrm{~m}$ long by $2.2 \mathrm{~m}$ wide, has $0.40 \mathrm{~m}$ and $0.5 \mathrm{~m}$ thick walls. At the base, the pile cap $\left(10 \times 6.75 \mathrm{~m}^{2}\right.$ and $2.5 \mathrm{~m}$ deep $)$

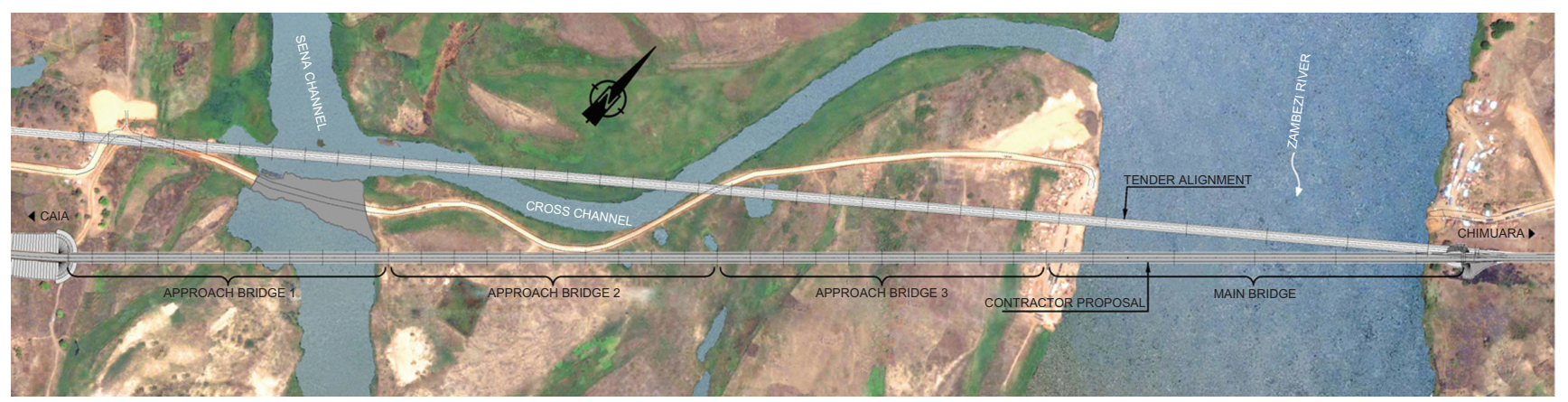

Figure 5. In-plan general bridge layout (Betar, 2006; WSP/LBG/ GRID, 2004) 


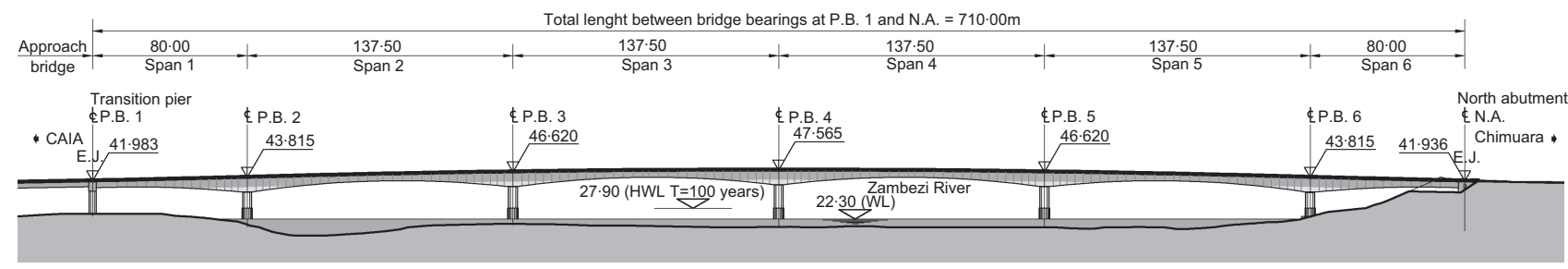

Figure 6. Main bridge layout ((dimensions in $\mathrm{m}$ )

transfers the loads to four piles of $1.5 \mathrm{~m}$ diameter (Figure 11). All approach bridge piers have a set of four piles of $1.5 \mathrm{~m}$ diameter, executed with temporary steel casing $12 \mathrm{~mm}$ thick. Piles have lengths from $48 \mathrm{~m}$ to $61 \mathrm{~m}$, with a minimum penetration of $5 \mathrm{~m}$ into layers $\mathrm{C} 2$ to $\mathrm{C} 4$. Concrete grade $\mathrm{C} 35 /$ 45 is adopted in the deck, while piers, piles and foundations are made with $\mathrm{C} 30 / 37$. In order to resist the longitudinal seismic forces the deck is fixed at the three central piers of each bridge section, and at the remaining piers it is supported by pairs of unidirectional sliding pot bearings.

Typical $56 \mathrm{~m}$ spans adopted 16 longitudinal prestress tendons at supports and 10 cables at span sections (Figure 12). At each construction joint 10 tendons were stressed, corresponding to six coupled tendons in the webs and four tendons with end anchorages at the top slab, which allowed the forward movement of the launching girder. One additional cable was installed at each web at the support section. All longitudinal prestress tendons are made of $19 / 1.5 \mathrm{~mm}$ dia. strands. Slab transversal prestressing adopted the same layout of the main bridge. The diaphragms are prestressed with two $19 \times 1.5 \mathrm{~mm}$ tendons (Figure 12).

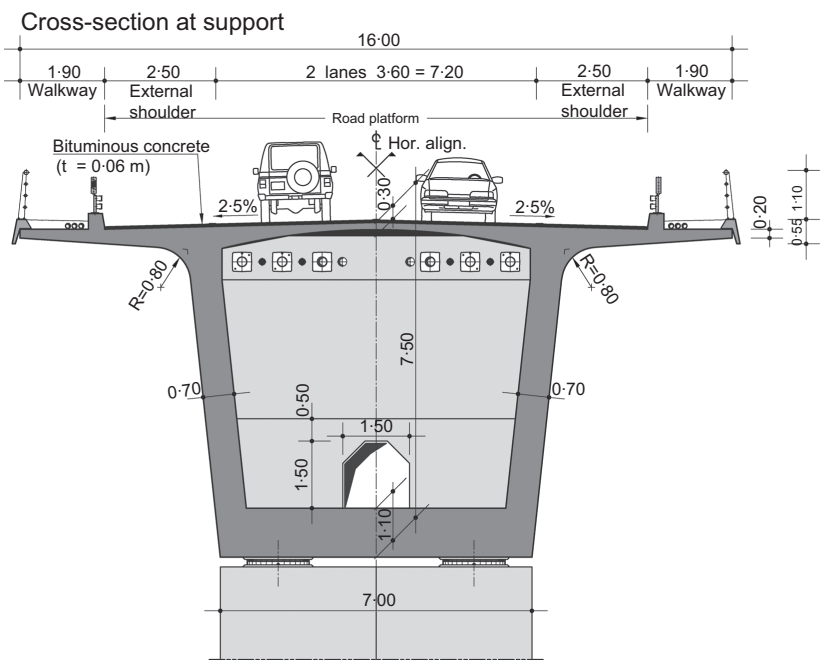

\subsection{Design criteria}

The design criteria and actions were based on the South African code (SATCC, 1998) as specified in the TOR (Table 3). International recommendations, namely the Eurocodes were adopted when necessary. ANE also requested the bridge to be checked for the live load actions as defined in the Portuguese code (RSA, 1983). The main reason for this requirement, not specified in the TOR, was due to the fact that most of the existing bridges in Mozambique had been designed according to the Portuguese codes.

During construction of the main bridge deck using the cantilever balanced method, equipment and live loads as well as wind loads acting on the deck surface were also considered. Most severe unbalanced load scenarios were considered to check the safety of the piers and temporary stability systems.

In service, ANE required the prestressed concrete deck to be checked as a class 1 member, which implied no tensile stresses allowed under load combinations involving $50 \%$ of NA live loading or NB18 vehicle composed by four axles with four wheels of $45 \mathrm{kN}$. It was also ensured for the service conditions,

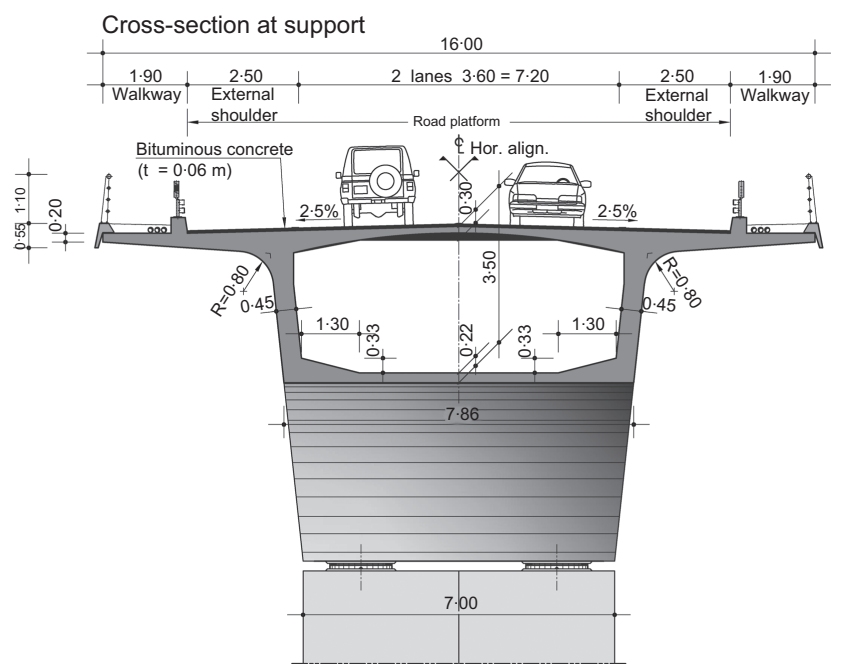

Figure 7. Main bridge deck cross-sections (dimensions in m) 

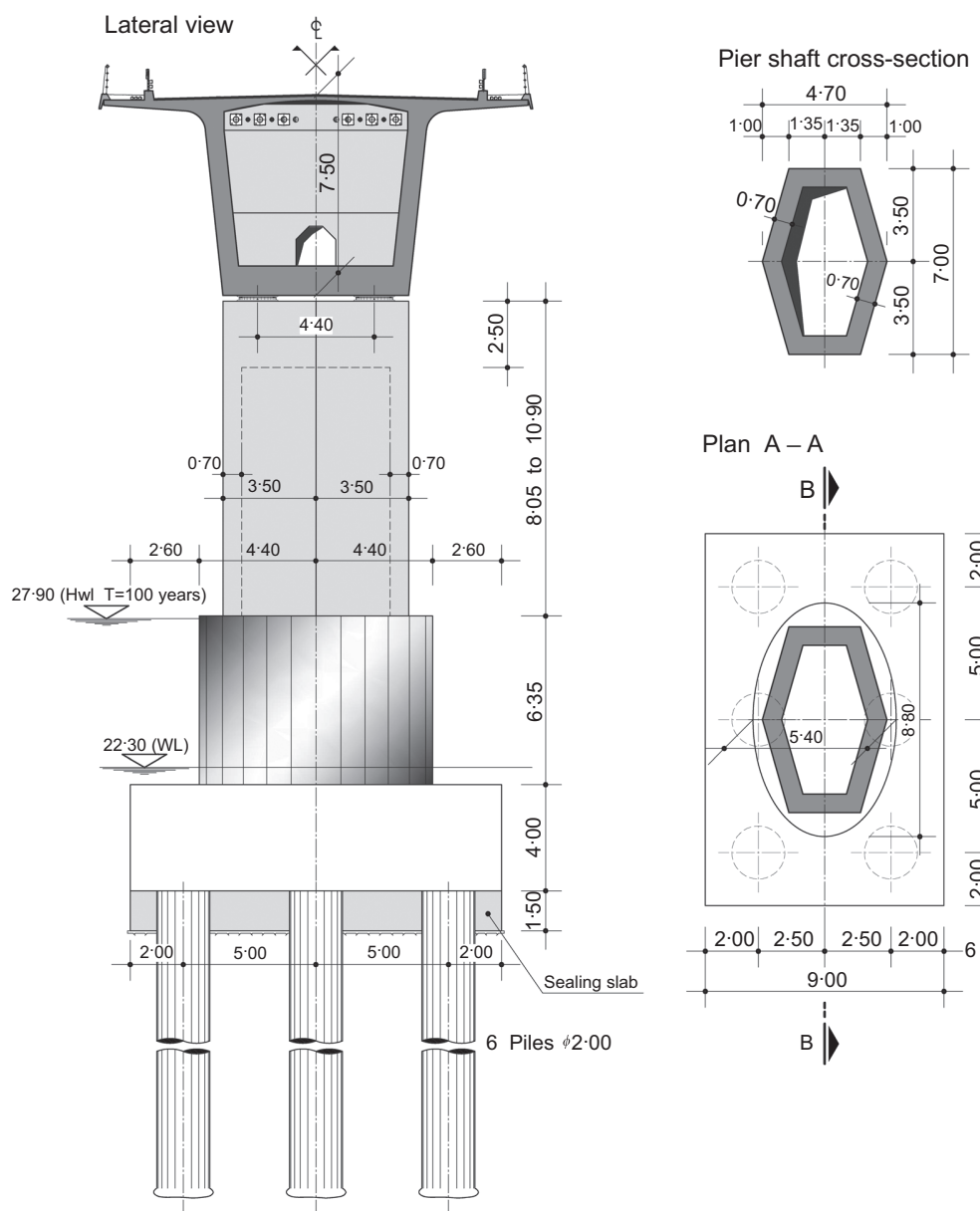

Plan A-A
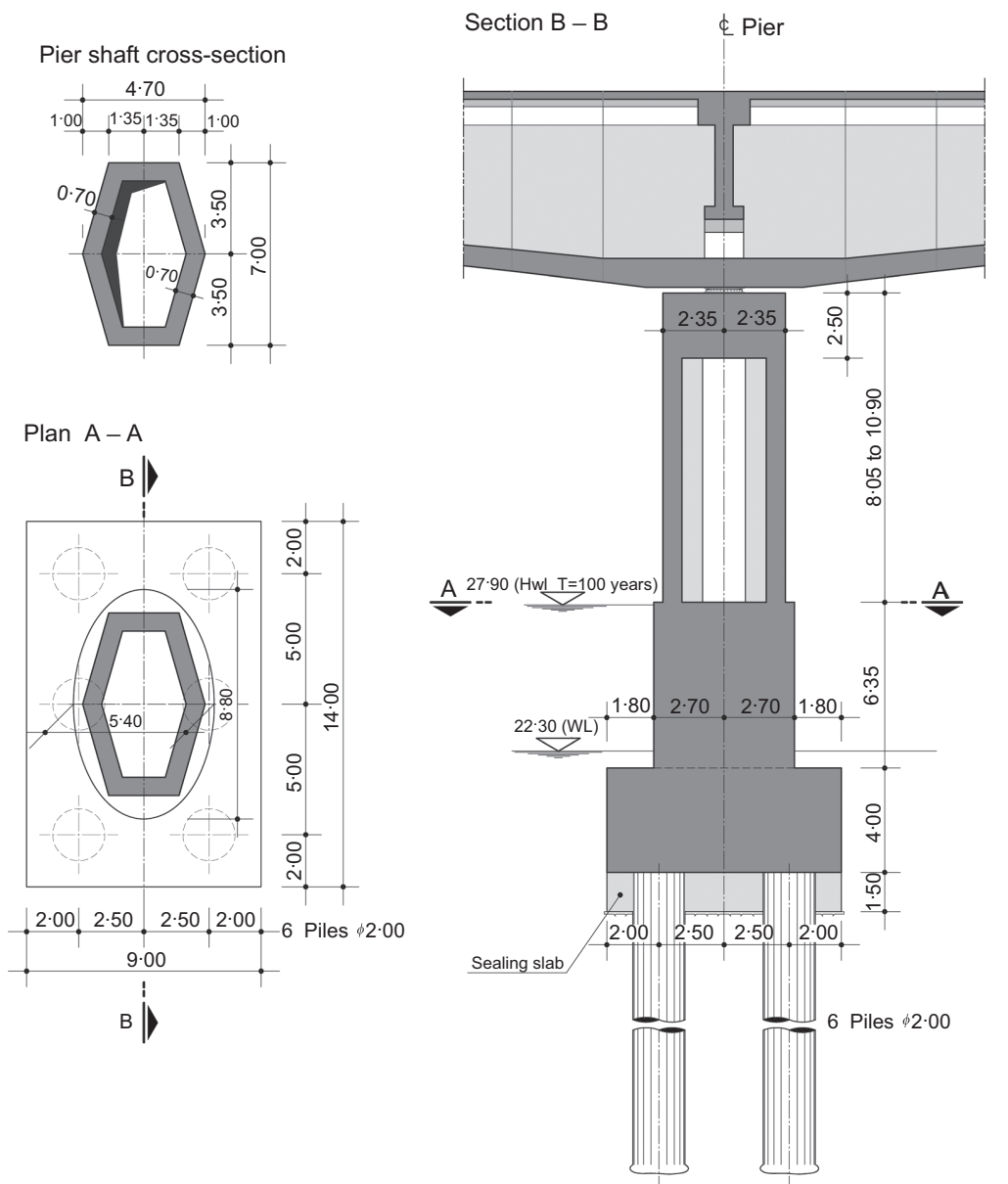

Figure 8. Main bridge piers and foundations (dimensions in $\mathrm{m}$ )

a crack width limit of $0.20 \mathrm{~mm}$ for a load combination that involved $100 \%$ of NA live loading, NB36 loading or NC loading, and $80 \%$ of temperature gradient.

Seismic forces were primarily estimated by static forces obtained considering $2 \cdot 5 \%$ or $3 \cdot 3 \%$ of the permanent load $\mathrm{G}$, multiplied by the square root of the first natural frequency $f_{o}$, in the corresponding direction. The difference between the two percentages was caused by a 1.3 importance factor considered for the main bridge. At the final design stage, a non-linear time history analysis was performed based on 20 accelerograms, considering the non-linear behaviour of the oleo-dynamic devices. These accelerograms were generated taking into account the seismicity and geological conditions of the site.

\section{Detailed design and construction works}

\subsection{Programme}

Four bidders prepared tenders between September and November 2005. The Mota Engil/Soares da Costa JV tender was accepted in December 2005 and design started straight away, although the contract award was not formalised until February 2006, site works were initiated in March 2006.

The 36-month contract period ran from 13 March 2006 to 12 March 2009, over three rainy seasons. The first two rainy seasons were especially severe and caused delays on foundation works. At the end, 80 additional days were required to conclude finishing works.

\subsection{Detailled design}

The contractor proposed an adjustment in the strait bridge inplan alignment, displacing the south abutment (from Caia side) $200 \mathrm{~m}$ downstream (see Figure 5), to avoid passing over the existing ferry access road and the Sena channel and improving safety for people and goods during bridge construction. This was accepted with no additional costs for ANE or extension of the completion date. The length of the approach road on the south side increased approximately 


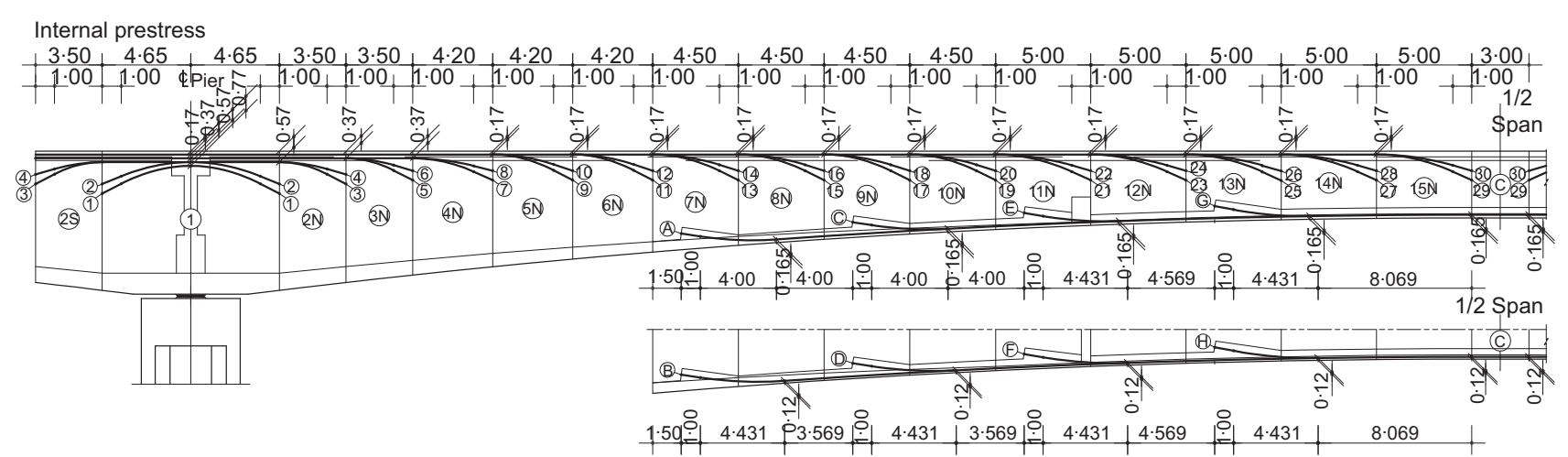

\begin{tabular}{l} 
External prestress \\
(25) \\
\hline \hline
\end{tabular}

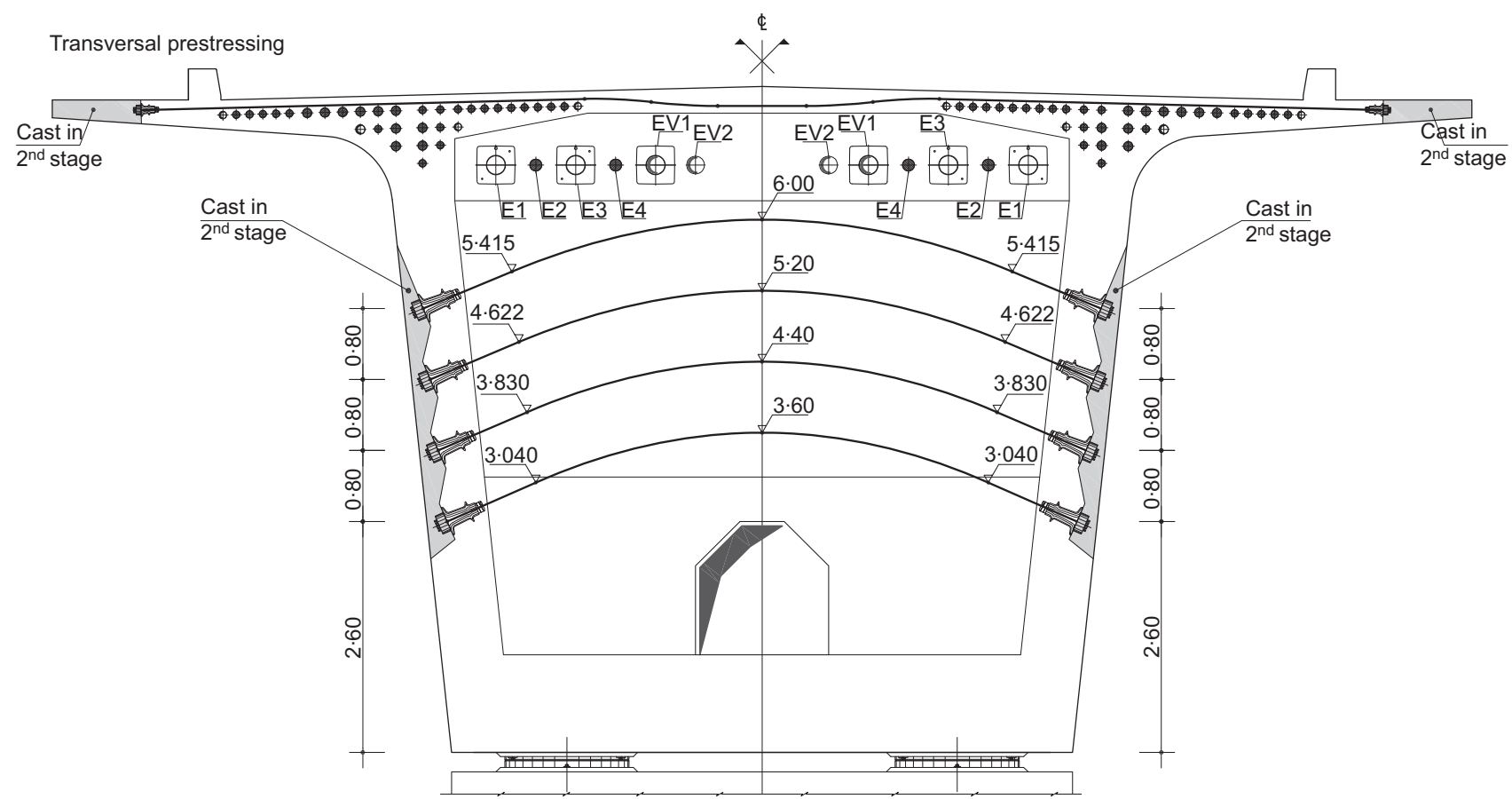

Figure 9. Main bridge prestressing layouts (dimensions in $\mathrm{m}$ )

$70 \mathrm{~m}$ for the new alignment compared with the base case alignment. This decision implied a further survey composed of 38 boreholes to confirm local geotechnical conditions. A detailed design (Betar, 2006) adopted the bridge geometry, prestressing and reinforcement layout of the base case design (Table 4) (WSP/LBG/GRID, 2005). 


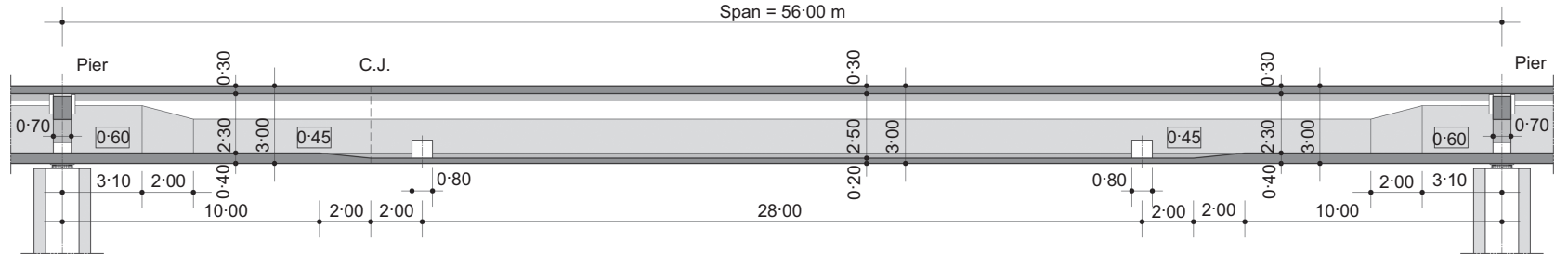

\section{Cross-section at support}

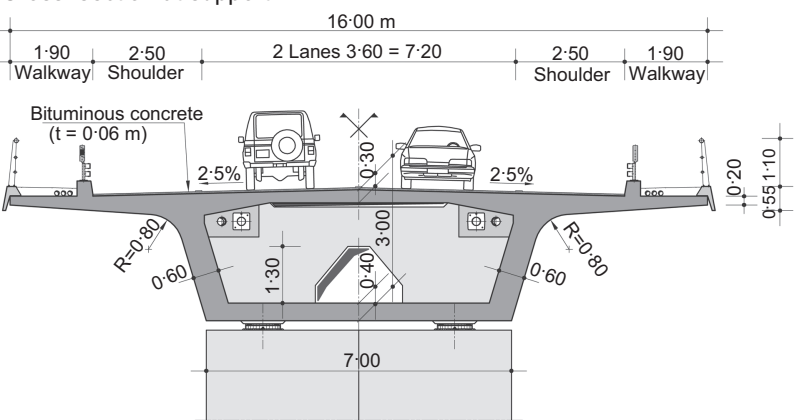

Cross-section at mid-span

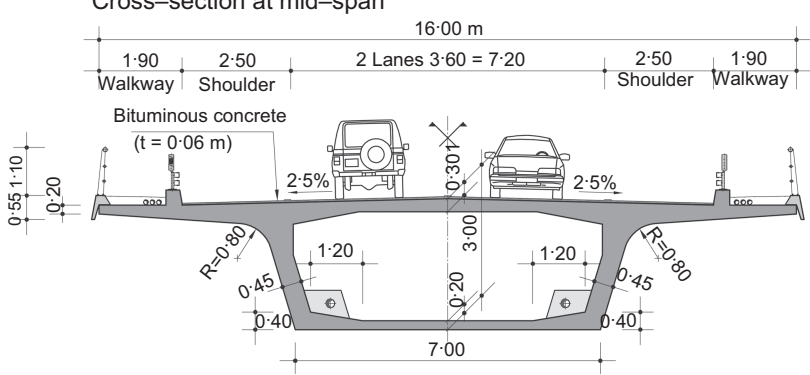

Figure 10. Approach bridge deck longitudinal layout and crosssections (dimensions in $\mathrm{m}$ )
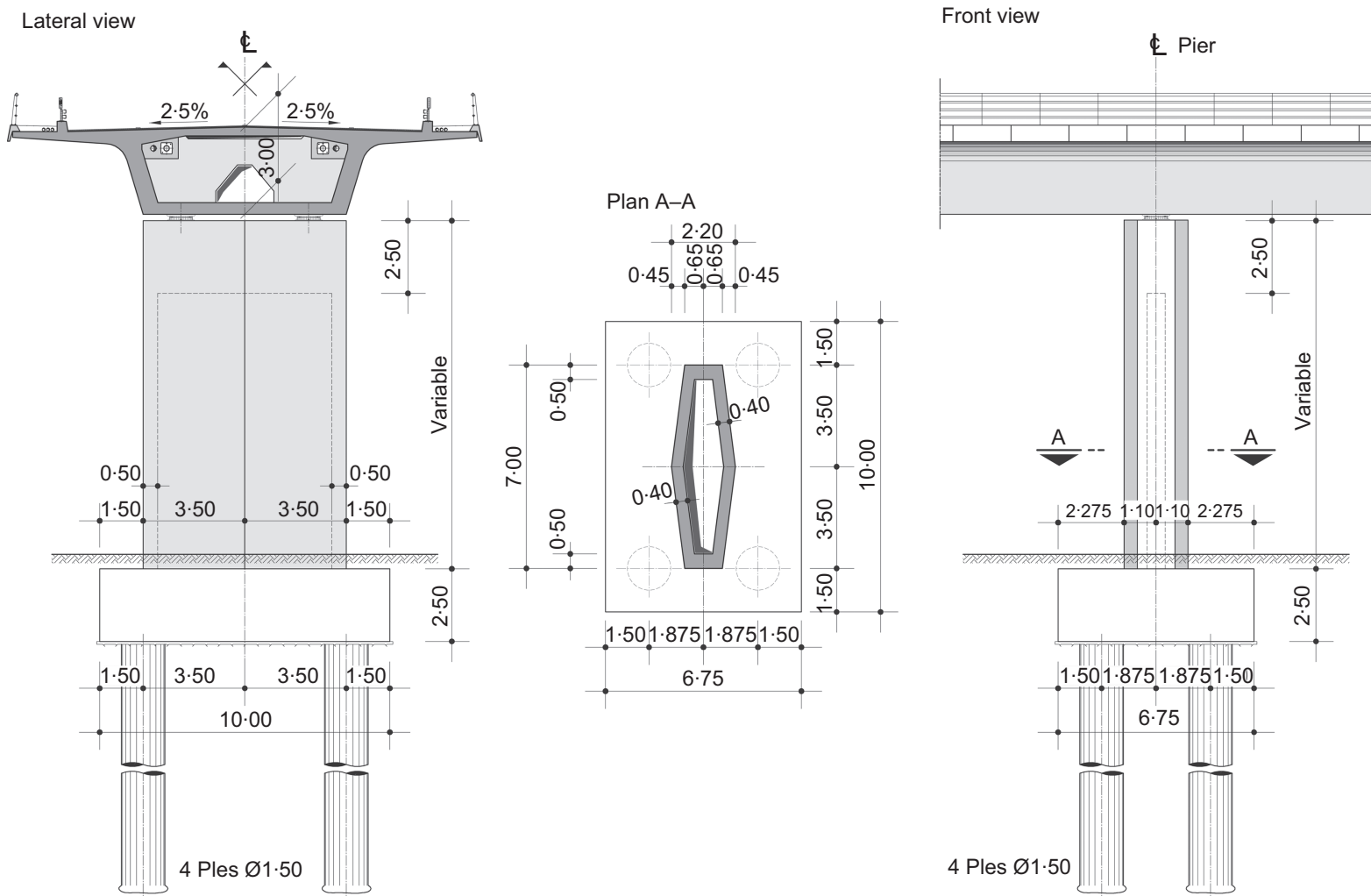

Figure 11. Approach bridge piers layout (dimensions in m) 


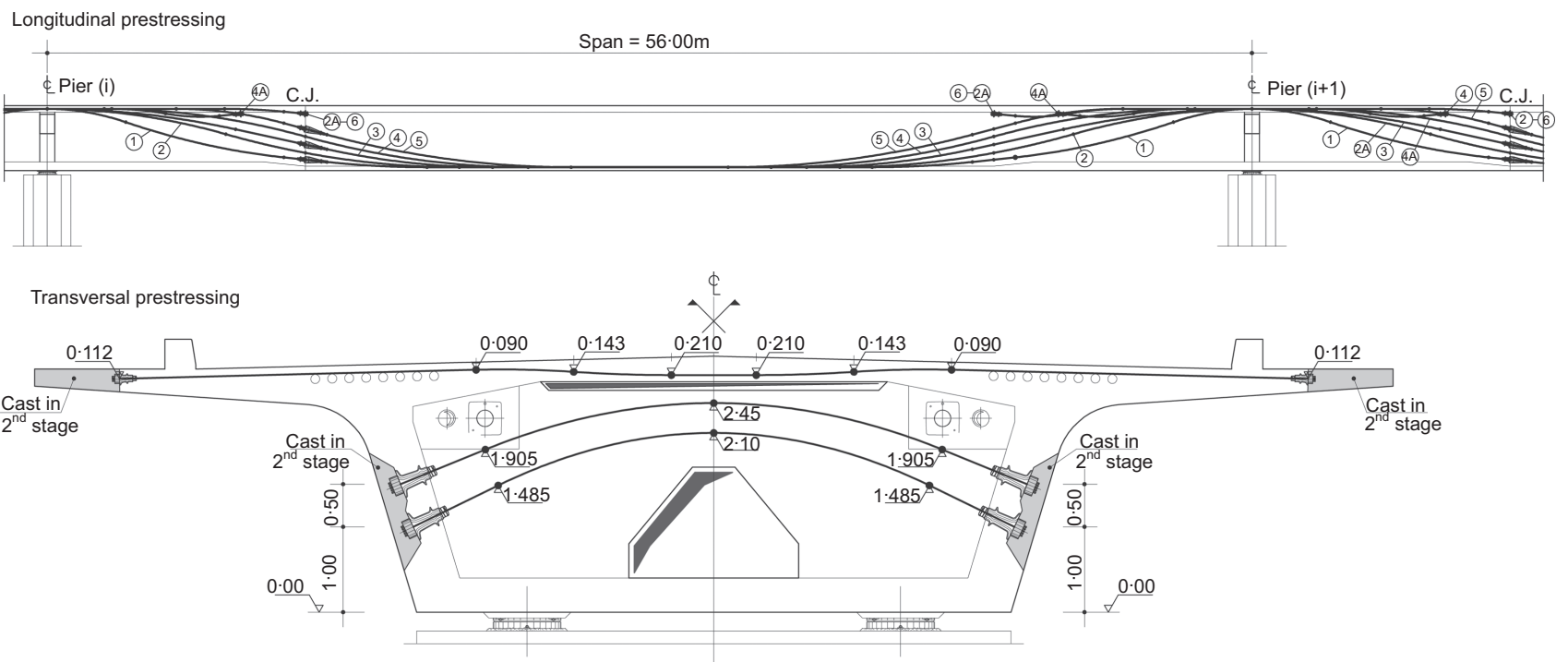

Figure 12. Approach bridge prestressing layout (dimensions in $\mathrm{m}$ )

\subsection{Piers and foundations}

During the first year subcontractor Trevi executed 132 piles for the approach bridge, one pile per day and six piles per week, using recoverable casing tubes. Sonic logging tubes were installed in every pile with the provision for some of the tubes to accommodate a further bore, in case it was felt necessary to core through the pile toe and rock interface for testing. This was done at 20 piles and a good bond was found. The Osterberg load test was successfully performed on 19 March 2007.

The 36 piles for the foundations of the main bridge had a significant delay due to the Zambezi River flood of January/ February 2007. The first $2 \mathrm{~m}$ dia. pile at the river, for pier PB2, was finished only in March 2007. The delays were also caused by initial difficulties in drilling the upper very dense soil, but especially the weathered rock and the very hard gneiss rock. Pile foundations continued during 2007, using additional heavy equipment brought by Trevi. A barge anchored to the permanent steel casing tubes was used to execute river piles (Figure 13).

Pile caps were executed using cofferdams. After placing sheet piling, river pile caps involved excavation and pouring of the sealing concrete, followed by placing reinforcement bars and pouring in dry condition (Figure 13). This work lasted from the summer of 2007 until late spring 2008 and was severely delayed and damaged by the severe river flood of January/ February 2008 (Figure 14). A peak level of $27.62 \mathrm{~m}$ was reached on 2 February, just a few centimetres below the 50year return period (Table 1). The water washed away the access road, opened the natural groove of the Sena channel to the lagoon, and overflowed the cofferdams of piers PB3 and PB4, which caused a 4 month delay in the main bridge construction. In the end, most of this delay was recovered as a result of the contractor's strong efforts. Pile caps of the main bridge piers were concreted using the sheet piles as formwork. Afterwards, sheet piles were cut at the pile caps level and left as an additional protection.

Pier shafts were concreted using climbing formwork systems. The approach bridge pier shafts were carefully dimensioned to suit the launching girder supports. Additional reinforcement had to be added to cope with the high load transmitted by the launching girder supports. The permanent pot bearings were installed at the pier tops. Typical piers have two guided bearings. Only the three central piers of each of the approach bridge segment and the PB4 pier segment of the main bridge have fixed bearings. The vertical load capacity of the bearings is $12000 \mathrm{kN}$ for the approach bridge and $35000 \mathrm{kN}$ for the main bridge.

\subsection{Main bridge deck}

The main bridge deck was built using the balanced cantilever construction method. Work started in December 2007 over pier PB5, and thereafter over PB6 (Figure 15). The closure between PB5, PB6 and the north abutment was executed in November 2008. The two pairs of form travellers, with nominal capacity of $2000 \mathrm{kN}$, were then moved to piers PB2 and PB3. Due to the severe flood seasons a third form traveller pair was brought by the contractor to recover the delay on PB4. The extremities of the end spans, $11 \mathrm{~m} \mathrm{long}$, were executed using scaffolding supported on piles. 
Dead load

Superimposed dead loads Traffic loads

Sidewalk loads

Thermal actions

Transversal wind

Earthquake

Ship impact

Flood even

Reinforced and prestressed concrete

Asphalt layer

Sidewalks (light concrete)

Kerbs

Guard rails

Parapets

Edge beams

Eurocode 2 - Part 1 (EN 1992-1-1: 2004)

NA loading: uniformly distributed load on four lanes ( $L=$ loaded span):

$\mathrm{q}_{\max }[\mathrm{kN} / \mathrm{m}]$

$$
\left\{\begin{array}{cl}
144 & \Leftarrow \mathrm{L} \leq 36 \mathrm{~m} \\
\frac{720}{\sqrt{\mathrm{L}}}+24 & \Leftarrow \mathrm{L}>36 \mathrm{~m}
\end{array}\right.
$$

Main

bridge

Apr. bridge

$\mathrm{L}[\mathrm{m}]$

$137 \cdot 5$

$80 \cdot 0$

$56 \cdot 0$

$\mathrm{q}_{\max }[\mathrm{kN} / \mathrm{m}]$

$85 \cdot 4$

$104 \cdot 5$

$120 \cdot 2$

added with a concentrated load with a maximum value for the four lanes loaded of $\mathrm{Q}_{\max }=401 \mathrm{kN}$ (equal to longitudinal traction or braking forces of vehicles attached to NA loading)

NB loading: vehicle (contact pressure: $1.0 \mathrm{MPa}$ ):

NB36 loading 4 axis with 4 wheels of $90 \mathrm{kN} /$ wheel

NB18 loading

4 axis with 4 wheels of $45 \mathrm{kN} /$ wheel

NC loading (multiwheel vehicle): uniformly distributed load of $150 \mathrm{kN} / \mathrm{m}$ in $40 \mathrm{~m}$

Uniformly distributed load depending on the loaded length $L$ :

$\mathrm{q}_{\max }[\mathrm{kN} / \mathrm{m}]$

Uniform temperature variation

Temperature gradient

Without live loads

With live loads

Approach bridge/main bridge

Ship dead load DTW $=500 t$

Ship velocity at impact $\mathrm{V}=5 \mathrm{knots}(2.6 \mathrm{~m} / \mathrm{s})$

Hydrodynamic pressure on pier shafts

Debris (addition concentrated force on each pier)

$\begin{array}{lrc} & L[\mathrm{~m}] & 9_{\max }[\mathrm{kN} / \mathrm{m}] \\ \text { Main } & 137 \cdot 5 & 6 \cdot 4 \\ \text { bridge } & 80 \cdot 0 & 8.4 \\ \text { Apr. bridge } & 56 \cdot 0 & 10 \cdot 0\end{array}$

$\Delta \mathrm{T}_{U}= \pm 20 \cdot 0^{\circ} \mathrm{C}$

$\Delta \mathrm{T}_{\mathrm{D}}= \pm 14 \cdot 4^{\circ} \mathrm{C}$

$\mathrm{W}_{\mathrm{T}}=2 \cdot 23 \mathrm{kN} / \mathrm{m}^{2}$

$\mathrm{W}_{\mathrm{T}}=1.03 \mathrm{kN} / \mathrm{m}^{2}$

$\mathrm{F}_{\mathrm{E}, \mathrm{H}}=0 \cdot 033 \cdot \sqrt{f_{o}} \cdot G$

$0 \cdot 98 \sqrt{\mathrm{DWT}} \mathrm{V} / 8[M N]=7122 \mathrm{kN}$

$7 \cdot 6 \mathrm{kN} / \mathrm{m}$

$180 \mathrm{kN}$

Table 3. Design loads according to SATCC (1998)

Sets of two temporary concrete columns $1.4 \times 1.0 \mathrm{~m}^{2}$ were placed at a distance of $3.8 \mathrm{~m}$ from the pier axe. Hydraulic jacks of $4000 \mathrm{kN}$ capacity were used to transfer the vertical loads to the piers, after construction of each three pairs of segments (Figure 16). The stability system was complemented with a set of two groups of $13 \phi 36$ bars and two inclined cables with 27/ $15 \mathrm{~mm}$ strands on both sides of the piers, anchoring segment 4 to the pile caps.

The balanced cantilever scheme preceded erecting 14 pair of segments, one pair each 7 days, until the closure segment. The last closure was achieved between PB3 and PB5 on 21 April
2009 (Figure 15). External cables were installed in May/June 2009, in parallel with the finishing works. All the stability systems were released and removed thereafter.

The concrete was monitored during all deck construction stages. Cube samples followed the same temperature and humidity profile as the deck and were then tested at regular intervals to prove the actual strengths required for stressing the tendons and moving the equipment. Typical early age strengths were between 30 and $40 \mathrm{~N} / \mathrm{mm}^{2}$ for stressing of cables (achieved at 3 days), approximately $40-50 \mathrm{~N} / \mathrm{mm}^{2}$ for 7 days and higher than $50 \mathrm{~N} / \mathrm{mm}^{2}$ at 28 days (Figure 17). The 7-28 
Bridge Engineering

Volume 166 Issue BE2
Design and construction of

Zambezi River Bridge,

\section{Mozambique}

Reis, Oliveira Pedro and Dalili
Main bridge

Concrete

Abutments and foundations: C30/37

Piers and pile caps: C30/37

Decks: C35/45

Steel

Mild steel: $\mathrm{f}_{\text {syd }}=435 \mathrm{MPa}$

Longitudinal prestress: 1500/1770 MPa:

Internal

External

Transversal prestress (slabs and diaphragms)

Piles

$1 \cdot 2$ m diameter

$1.5 \mathrm{~m}$ diameter

$2 \cdot 0 \mathrm{~m}$ diameter

$$
\begin{array}{r}
3469 \mathrm{~m}^{3} \\
2150 \mathrm{~m}^{3} \\
11000 \mathrm{~m}^{3}
\end{array}
$$

$1850 \mathrm{t}$

$432 \cdot 56 \mathrm{t}-39 \cdot 3 \mathrm{~kg} / \mathrm{m}^{3}$

$102 \cdot 65 \mathrm{t}-9 \cdot 33 \mathrm{~kg} / \mathrm{m}^{3}$

$47 \cdot 7 \mathrm{t}-4 \cdot 34 \mathrm{~kg} / \mathrm{m}^{3}$

$281 \mathrm{~m}$

$-$

$1080 \mathrm{~m}$
Approach bridge

$5539 \mathrm{~m}^{3}$
$3575 \mathrm{~m}^{3}$
$18600 \mathrm{~m}^{3}$

$3450 \mathrm{t}$

$480 \cdot 0 \mathrm{t}-25 \cdot 8 \mathrm{~kg} / \mathrm{m}^{3}$

$110 \cdot 7 \mathrm{t}-5 \cdot 95 \mathrm{~kg} / \mathrm{m}^{3}$

$843 \mathrm{~m}$

$6304 \mathrm{~m}$

Table 4. Principal bridge quantities

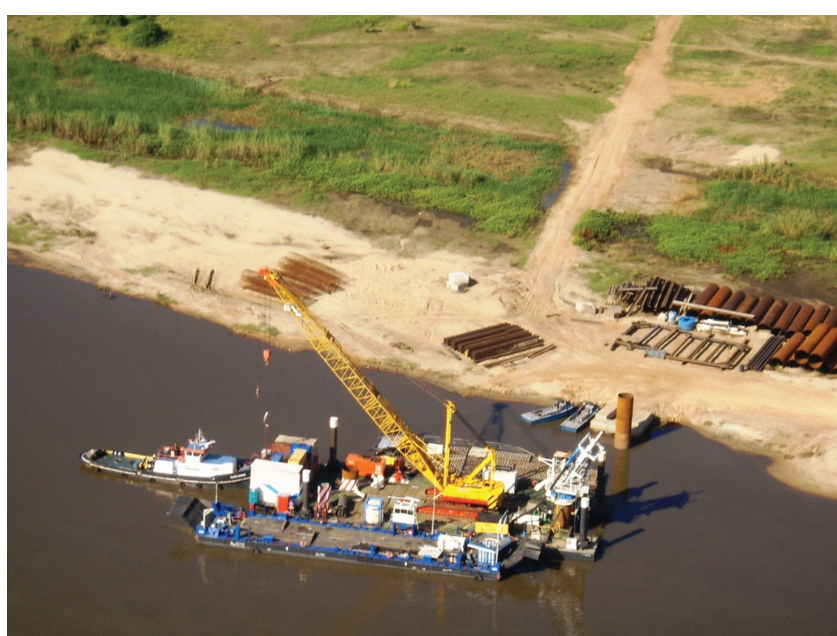

(a)

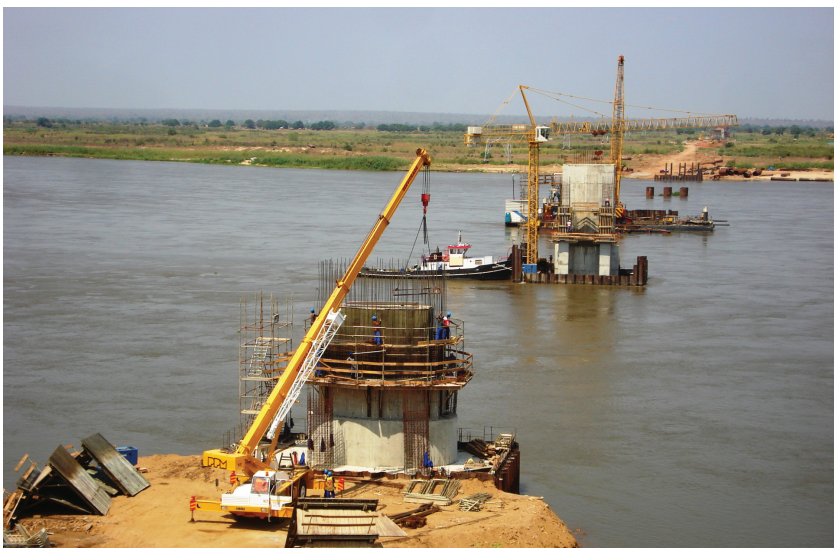

(b)

Figure 13. Main bridge pier and foundation works

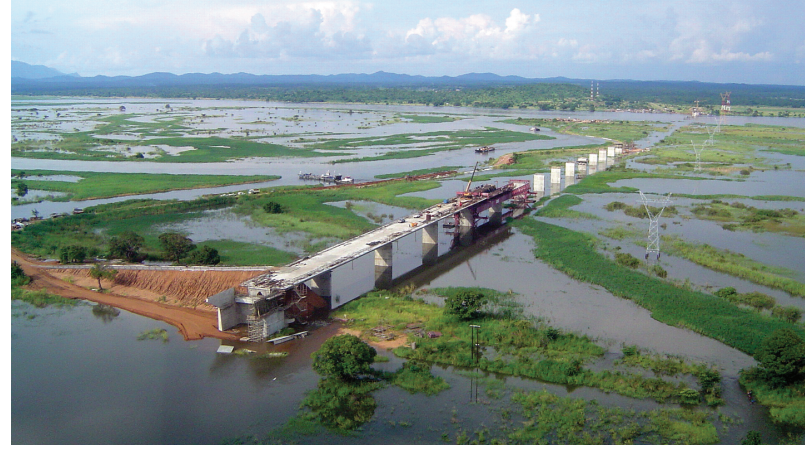

(a)

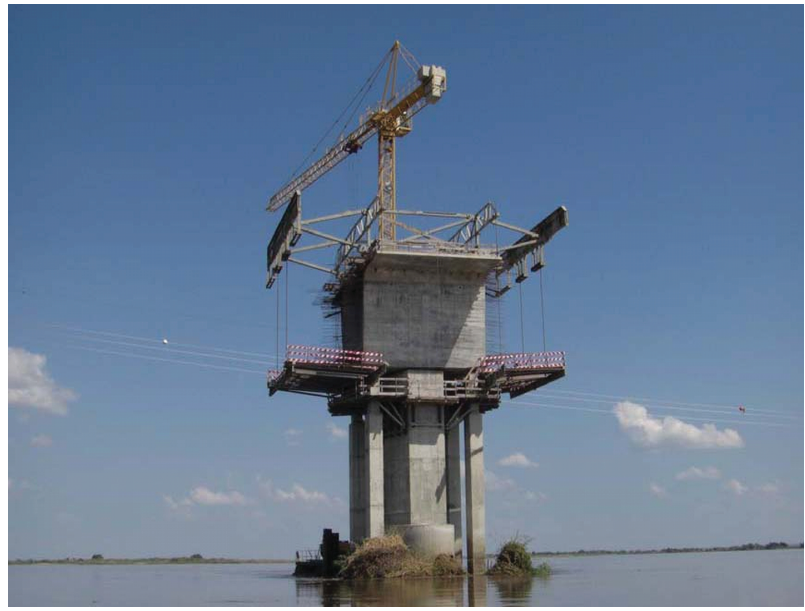

(b)

Figure 14. Flood of January/February 2008 
Bridge Engineering

Volume 166 Issue BE2
Design and construction of

Zambezi River Bridge,

Mozambique

Reis, Oliveira Pedro and Dalili

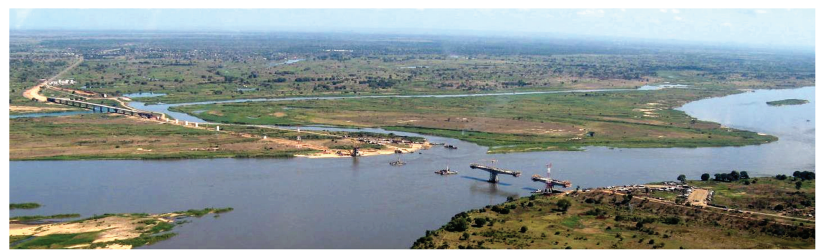

(a)

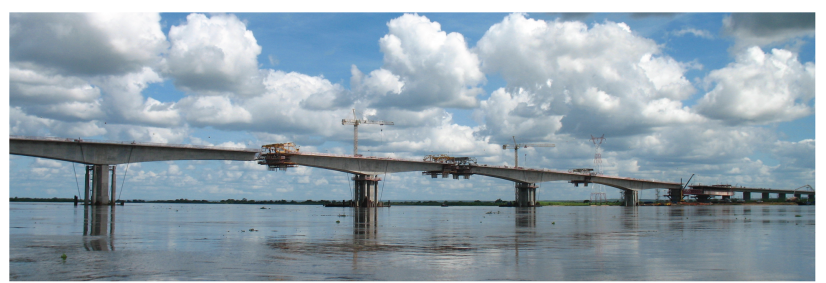

(b)

Figure 15. Main bridge construction works

days hardening strength factor was regularly between 0.8 and $0 \cdot 9$, confirming that the concrete had consistently high strengths at early stages.

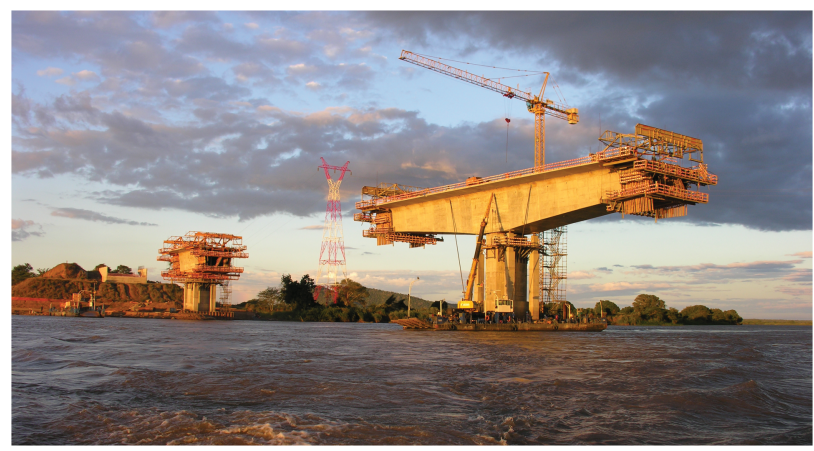

(a)

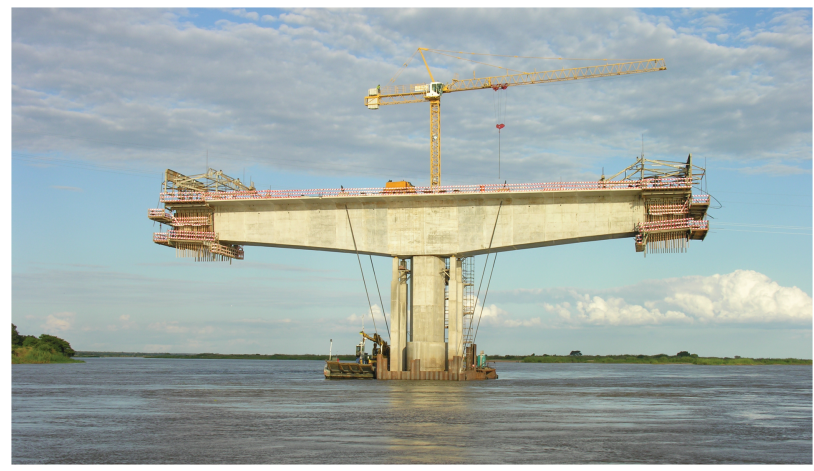

(b)

Figure 16. Main bridge PB5 cantilever with the deck stability system
The time-dependent properties of concrete used in design models was also confirmed using actual concrete adopted in construction, namely for the main bridge deck. Creep and shrinkage tests were conducted at the Portuguese National Laboratory of Civil Engineering, reproducing the expected in-situ temperature and humidity profile (LNEC, 2009). Shrinkage strain and creep coefficients were obtained considering concrete ages of 3,7 and 28 days at the time of loading. Results were compared with the proposed variation laws of Eurocode 2 parts 1 and 2 (EN 1992-1-1, 2004; EN 1992-2, 2005). A better agreement was obtained with the expressions proposed by Eurocode 2-1 for high strength concrete executed with rapid hardening cement (class R) (Figure 17).

\subsection{Approach bridge deck}

The execution scheme of the approach bridge deck was based on a segmental construction method, span by span with construction joints $12 \mathrm{~m}$ apart from piers. A formwork launching girder working below was adopted. The launching girder was supported at the back by the deck cantilever and at the front by the adjacent pier. A new formwork launching girder was installed on site by June 2007 (Figure 18). It represented a total steel weight of approximately $7000 \mathrm{t}$, which proved to be critical for the deck section over the piers. Ten additional prestress bars $\phi 36$ were added to the longitudinal prestressing over the supports to avoid having tensile stresses at deck support cross-sections for the bending moment generated by casting of one span. These bars were moved together with the launching girder.

To facilitate internal box-girder formwork handling from one span to the next, the contractor proposed to cast diaphragms in a second stage. Extra transversal prestressing was locally added to the slab to avoid having tensile stresses before casting the diaphragms. The typical 2-week cycle for each $56 \mathrm{~m}$ span was actually achieved after two spans and was then refined to achieve an optimum cycle of 12 working days. The first span next to the south abutment was cast on 21 August 2007 and after 29 additional spans the last one, adjacent to the main bridge, was finally cast on 9 April 2009.

\subsection{Safety}

A health and safety programme according to international regulations was established on the construction site, which was implemented by a health and safety officer. This programme was controlled by the supervision team. Each activity on site was described by a method of statement including safety analyses scrutinised and approved by the supervision team before execution.

The methods of design and construction, with typical repetitive deck construction procedures executed by worker teams 


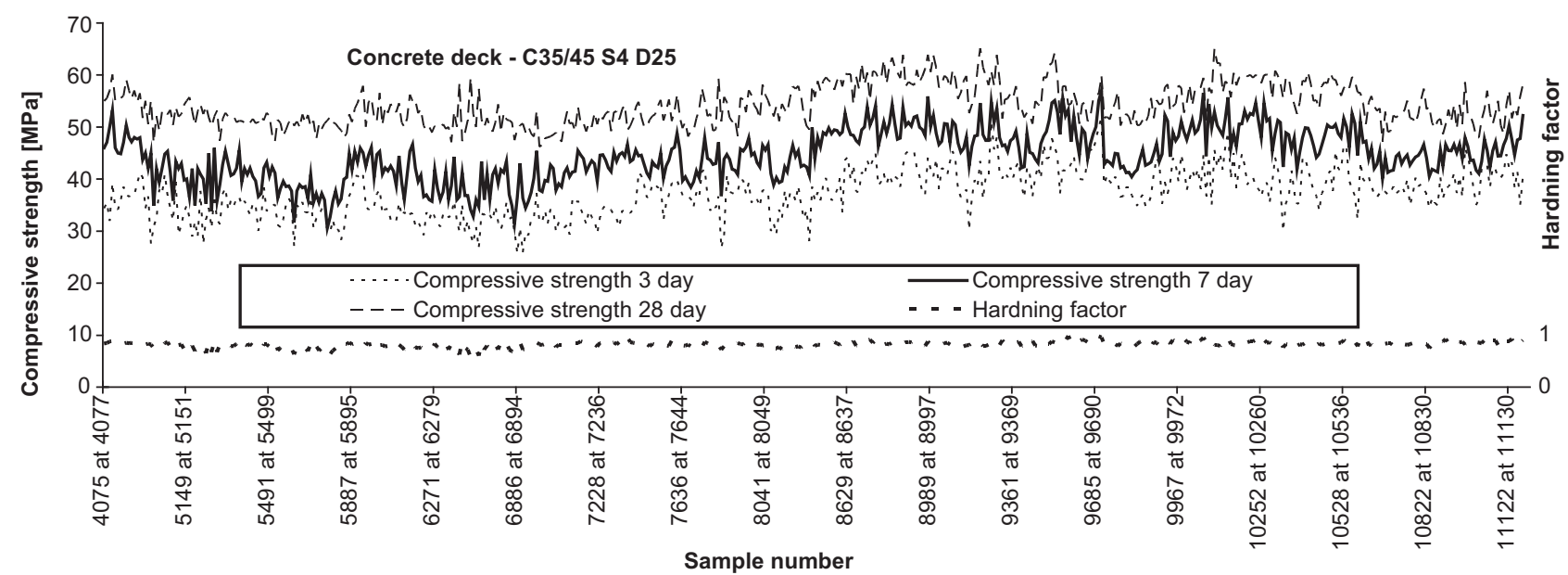

(a)

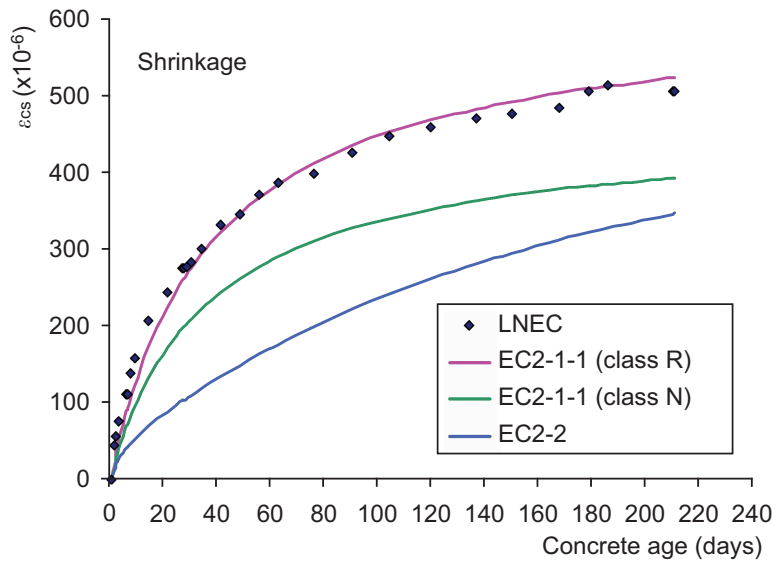

(b)

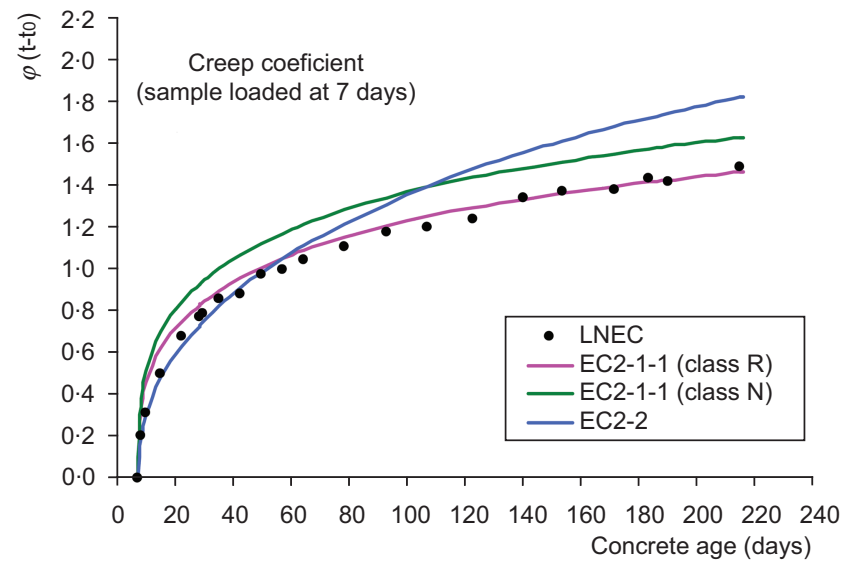

(c)

Figure 17. Concrete C35/45 monitored during deck construction (LNEC, 2009)

prepared for the work, ensured that the safety of the workforce was always highly controlled. Three years of intense work were completed with no major accidents on the bridge site, which is a tribute to the chosen construction processes, the care taken in their preparation and the vigilance of the site team.

\subsection{Finishes and deck load test}

Kerbs and edge beams work started on May 2009. The parapet edge beams were precast in $1.5 \mathrm{~m}$ lengths and attached to the deck with an in-situ stitch. To gain time the contractor proposed to start finishes within the cantilever deck. However, in order to avoid additional weight and to generate a final acceptable profile, it was determined that all edge beams were better installed after the deck was completed. Variable asphalt layer thickness ensured a good bridge profile. In some minor areas a final regularisation was needed before the asphalt layer was applied. The steel parapets were $1.1 \mathrm{~m}$ high. Guard rails had posts at $1.5 \mathrm{~m}$ centres fixed to high profile kerbs, and with a two-rail system to protect the footpaths.

Main bridge external prestressing and seismic devices were installed after all concreting works were finished (Figure 19). Two expansion joints at the ends and three at transition piers were placed in early June 2009 (Figure 19). These joints were provided within the depth of the carriageway surfacing and accommodated movements of up to $850 \mathrm{~mm}$ for the expansion joint between the main bridge and the approach bridge. A compression preset was defined for the joints due to irreversible displacements caused by time-dependent effects.

Scour protection was executed on all piers and consisted of rock riprap areas over and around the pile caps, with an average diameter of $\mathrm{D}_{50}=200 \mathrm{~mm}$ and $400 \mathrm{~mm}$, respectively, for the approach and main bridge. 
Bridge Engineering

Volume 166 Issue BE2
Design and construction of

Zambezi River Bridge,

Mozambique

Reis, Oliveira Pedro and Dalili

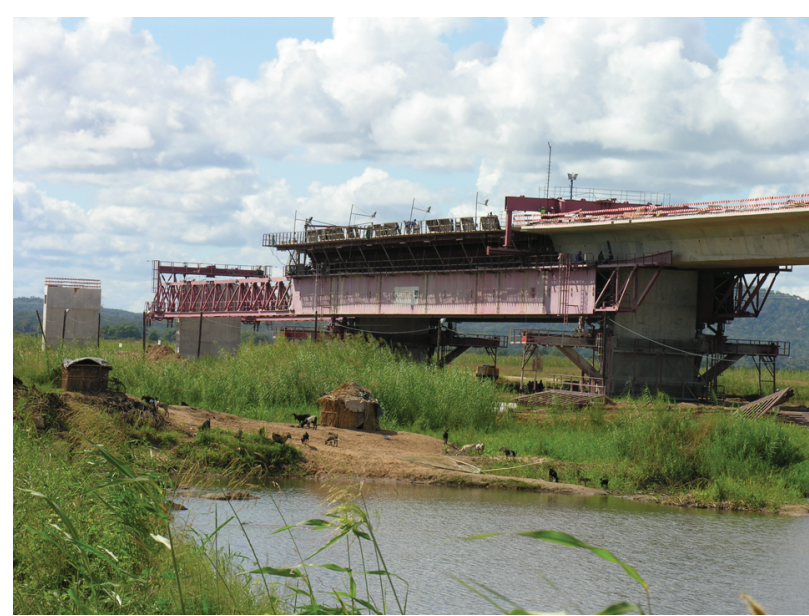

(a)

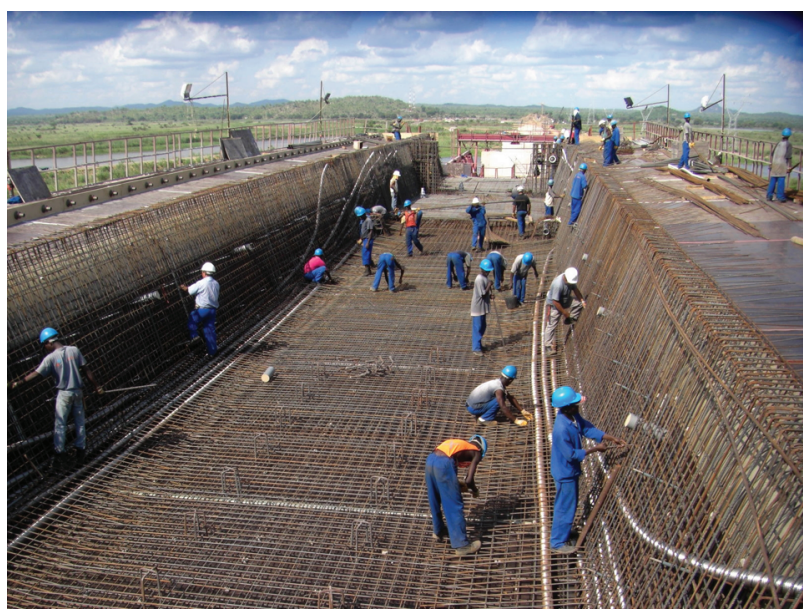

(b)

Figure 18. Approach bridge construction works

Access to the deck was provided at the abutments. Lighting was provided on both the main bridge and approach bridge decks to ensure proper inside access. The inside of the box girders was ventilated by $150 \mathrm{~mm}$ dia. holes $5 \mathrm{~m}$ apart in the webs. The carriageway also had highway lighting.

At the end of June 2009 a bridge load test was performed using 26 trucks weighing $30 \mathrm{t}$ each. Ten load positions were considered on both the main and approach bridge. Theoretical vertical displacements were compared with measured results, attaining a very good agreement.

\subsection{Environmental and socioeconomic} considerations

For the mitigation of environmental impact a site officer was appointed by the contractor and was monitored semi-annually by an environmental expert and daily controlled by the

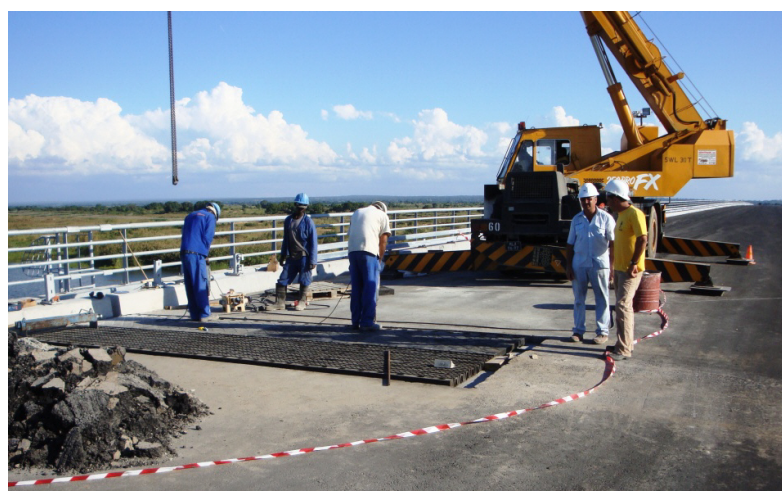

(a)

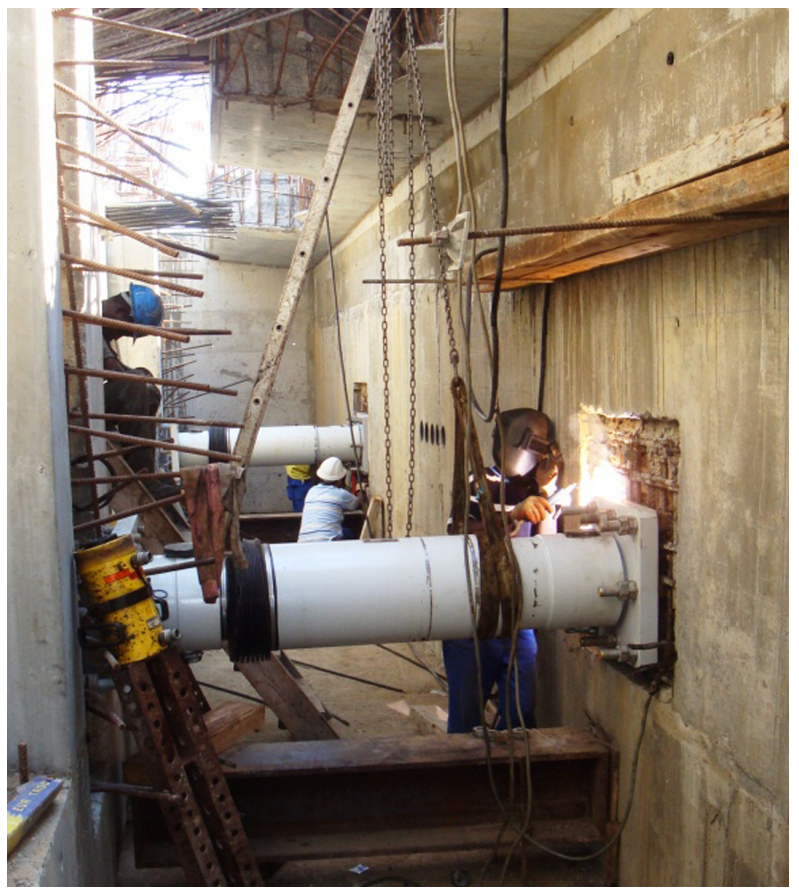

(b)

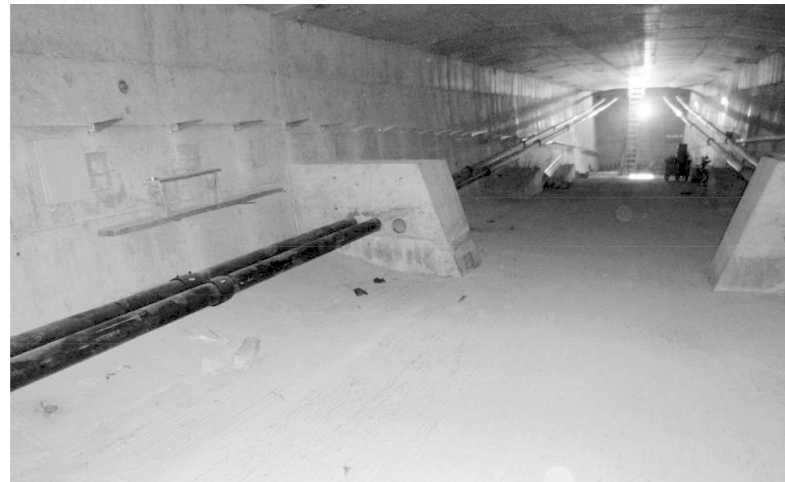

(c)

Figure 19. Finished works: expansion joints, seismic devices and external prestressing 
Design and construction of

Zambezi River Bridge,

Mozambique

Reis, Oliveira Pedro and Dalili

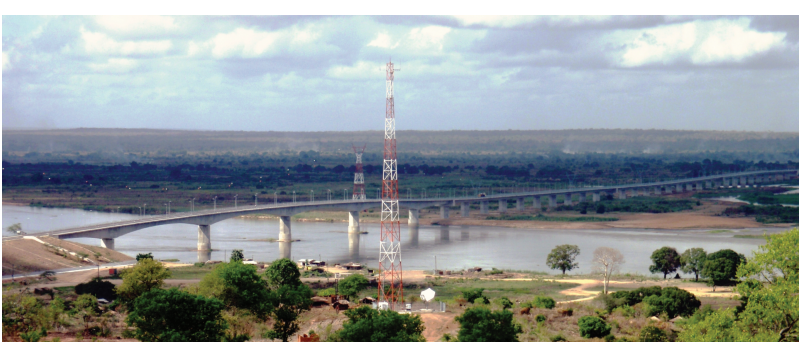

(a)

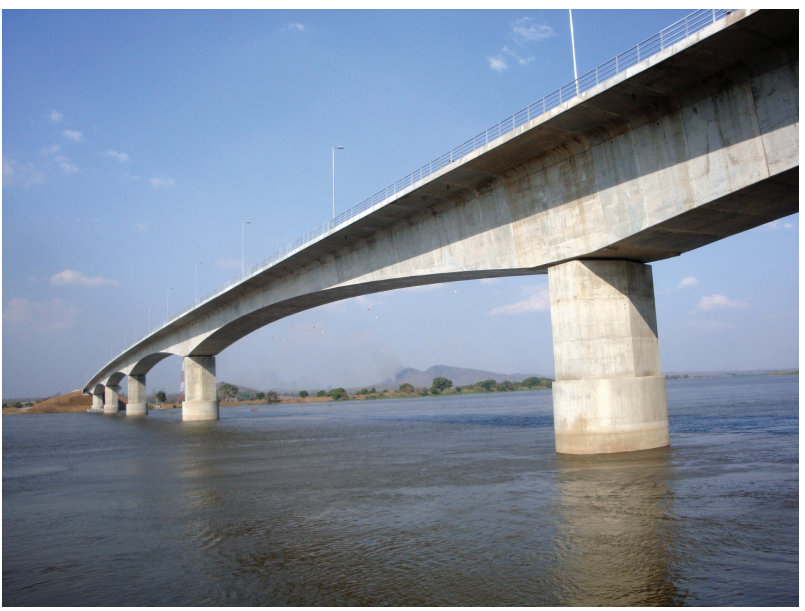

(b)

Figure 20. Views of the completed bridge

supervision team. For this purpose an environmental mitigation impact control plan was obtained in accordance, partly with the contract requirements, and partly in consideration of the construction site's special nature.

A HIV/AIDS programme was implemented with the aim of providing an appropriate HIV/AIDS awareness and prevention programme. A medical clinic was installed and worked during the 36-month construction period to support the relevant components of the programme.

\section{Conclusions}

This major crossing of the Zambezi River at Caia has been completed on time by a design and construction team that has worked closely together in cooperation with the client (Figure 20). The $2376 \mathrm{~m}$ long bridge was built 40 years after the first design was presented, to become one of the longest bridges in Africa. This was achieved safely within a very difficult environment and in spite of two consecutive very severe rainy seasons. The design team worked to develop ideas from previous projects to create a simple and reliable bridge design that successfully overcame all constraints experienced by the contractor and engineer team on site.
The project was completed with minimal environmental impact through a design and construction process that had addressed these issues at every turn. The bridge was opened by the president of Mozambique, Armando Emílio Guebuza, on 1 August 2009, and was named the Armando Guebuza Bridge.

\section{Acknowledgements}

Many people have contributed to this project. Unfortunately, limits on space allow only a small number to be noted here, but the authors' thanks go to everyone involved. In particular, the authors must thank:

- Elias Paulo, Vicente Miranda, ANE, National Road Administration of Mozambique

- Nuno Henriques, Gaspar Nunes, Mota-Engil/Soares da Costa JV

- Jorge Simões, WSP Group Africa, Johannesburg, South Africa

- Luís Macedo, The Louis Berger Group, Mozambique

- Fernando and Pedro Guedes de Melo, Consulgeo Geotechnical Consultants, Lisbon, Portugal

- Tiago Mendonça, Victor Brito, Manuel Almeida, Betar Consultants, Lisbon, Portugal

- António Baptista, prestress detailed designer

- Rui Mestre, Cláudio Baptista, João Sales, Luís Miranda, GRID Consulting Engineers, Lisbon, Portugal.

\section{REFERENCES}

Betar (2006) Zambezi River Bridge at Caia. Detailed Design of the Main Bridge and Approach Bridge.

Brokonsult (2001) Consulting Services for Zambeze River Crossing at Caia in Mozambique - Final Report with addenda.

Cardoso E (1971) Projecto da Ponte rodoviária sobre o rio Zambeze (in Portuguese).

CETA and Construções Técnicas (1982) Ponte sobre o rio Zambeze - Caia - Fundações e pilares. Vol I (in Portuguese).

Construções Técnicas (1982) Ponte sobre o rio Zambeze - CaiaParecer sobre as fundações. Vol VI (in Portuguese).

EN 1992-1-1 (2004) Eurocode 2: Design of concrete structures Part 1.1: General rules and rules for buildings. CEN, Brussels, Belgium.

EN 1992-2 (2005) Eurocode 2: Design of concrete structures Part 2: Concrete bridges - Design and detailing rules. CEN, Brussels, Belgium.

Karlsson M (2003) Zambezi River crossing at Caia in Mozambique - Vägverket Konsult Report. Swedish National Road Administration Consulting Service, Sweden.

LNEC (2009) Estudo de fluência do betão para a obra de construção da ponte sobre o rio Zambeze - Final Report (in Portuguese).

LOADTEST (2007) Report on drilled pile load testing (Osterberg 
method). P.V14 test pile - Zambezi River Bridge, Caia, Mozambique.

Melo PG (2007) Zambezi River - Approach Bridge Detail Design Review. O-Cell Pile Load Test. WSP/LBG/GRID Review report no 14

Menn C (1991) Prestressed Concrete Bridges, 2nd edn. Birkäuser Verlag,

Mott MacDonald (1997) Improvements to crossing of the Rio Zambeze at Caia on Road EN225. Geotechnical Report and Hydrology and Hydraulics Report.

Reis A (2006) Ponte sobre rio Zambeze em Moçambique. Desenvolvimento histórico do projecto e concepção da obra. In Proceedings of the 4th Portuguese Structural
Engineering Meeting, Lisbon. LNEC. pp. 338-349 (in Portuguese).

RSA (1983) Regulamento de Segurança e Acções em Estruturas de Edifícios e Pontes. Portuguese Code of Design Safety and Actions (in Portuguese).

SATCC (1998) South African Code of Practice for the Design of Road Bridges and Culverts.

WSP/LBG/GRID (WSP International Sweden/Louis Berger Group/GRID Consulting Engineers) (2004) Caia Bridge. Pre-design and Supervision: Preliminary Design Report.

WSP/LBG/GRID (2005) Caia Bridge. Pre-design and Supervision: Base Case Design Report.

\section{WHAT DO YOU THINK?}

To discuss this paper, please email up to 500 words to the editor at journals@ice.org.uk. Your contribution will be forwarded to the author(s) for a reply and, if considered appropriate by the editorial panel, will be published as discussion in a future issue of the journal.

Proceedings journals rely entirely on contributions sent in by civil engineering professionals, academics and students. Papers should be 2000-5000 words long (briefing papers should be 1000-2000 words long), with adequate illustrations and references. You can submit your paper online via www.icevirtuallibrary.com/content/journals, where you will also find detailed author guidelines. 